University of Wollongong

Research Online

Faculty of Business - Papers (Archive)

Faculty of Business and Law

$1-1-2015$

Multi-criteria decision analysis with goal programming in engineering, management and social sciences: a state-of-the art review

Cinzia Colapinto

Ca'Foscari University of Venice

Raja Jayaraman

Khalifa University

Simone Marsiglio

University of Wollongong, simonem@uow.edu.au

Follow this and additional works at: https://ro.uow.edu.au/buspapers

Part of the Business Commons

Research Online is the open access institutional repository for the University of Wollongong. For further information contact the UOW Library: research-pubs@uow.edu.au 


\title{
Multi-criteria decision analysis with goal programming in engineering, management and social sciences: a state-of-the art review
}

\author{
Abstract \\ Goal programming (GP) is an important class of multi-criteria decision models widely used to analyze and \\ solve applied problems involving conflicting objectives. Originally introduced in the 1950 s by Charnes et \\ al. (Manag Sci 2:138-151, 1955) the popularity and applications of GP has increased immensely due to \\ the mathematical simplicity and modeling elegance. Over the recent decades algorithmic developments \\ and computational improvements have greatly contributed to the diverse applications and several \\ variants of GP models. In this paper we present a state of the art literature review on GP applications in \\ three selected (prominent and popular) areas, namely engineering, management and social sciences.

\section{Keywords} \\ analysis, goal, programming, engineering, management, social, sciences, state, multi, criteria, art, \\ decision, review \\ Disciplines \\ Business

\section{Publication Details} \\ Colapinto, C., Jayaraman, R. \& Marsiglio, S. (2017). Multi-criteria decision analysis with goal programming \\ in engineering, management and social sciences: a state-of-the art review. Annals of Operations \\ Research, 251 (1-2), 7-40.
}




\title{
Multi-Criteria Decision Analysis with Goal Programming in Engineering, Management and Social Sciences: a State-of-the Art Review*
}

\author{
Cinzia Colapinto $^{\dagger} \quad$ Raja Jayaraman ${ }^{\ddagger} \quad$ Simone Marsiglio $^{\S}$ \\ Forthcoming in Annals of Operations Research
}

\begin{abstract}
Goal programming (GP) is an important class of multi-criteria decision models widely used to analyze and solve applied problems involving conflicting objectives. Originally introduced in the 1950s by Charnes et al. (1955) the popularity and applications of GP has increased immensely due to the mathematical simplicity and modeling elegance. Over the recent decades algorithmic developments and computational improvements have greatly contributed to the diverse applications and several variants of GP models. In this paper we present a state of the art literature review on GP applications in three selected (prominent and popular) areas, namely engineering, management and social sciences.
\end{abstract}

Keywords: Goal Programming; MultiCriteria Decision Analysis; Multi-Criteria Optimization; Recent Advances

\section{Introduction}

Multi-criteria decision making and goal programming (GP) models are important tools of operations research and management science with extensive applications in science, engineering, and social sciences. The complexity in most real world problems is due to difficulties in modeling and solving with single objective. GP models are a distance based method that optimizes multiple goals by minimizing the deviations of objectives from aspiration levels or goals set by the decision maker (DM). When the deviations are driven to zero the set goals of the model can be achieved, additionally the deviations can be either positive and negative signifying overachievement or underachievement of the goals subject to multiple constraints. Originally introduced as an extension to linear programming models by Charnes et al. (1955), a more elaborate treatment of GP models can be found in Charnes and Cooper (1961). The popularity of the GP models are expanded through the influential works of Lee (1972) and Ignizio (1976). As noted by Romero (1991), GP is the most widely used multi-criteria decision making technique. The GP modeling framework is easy to understand and apply and can be solved using most commercial mathematical programming softwares.

Standard GP models deal with deterministic goals that are precisely defined. Variants to standard GP models includes lexicographic GP (LGP) where the model is optimized according to DM's prioritized choice, and weighted GP (WGP) where positive and negative deviations from goals can differ according to the

${ }^{*}$ This work was supported by funding from Office of Research Support, Internal Research Fund (KUIRF) - Grant number 210032, Khalifa University. This work has been carried out and completed during research visits of Cinzia Colapinto at Khalifa University.

${ }^{\dagger}$ Ca’ Foscari University of Venice, Department of Management, Venice, Italy. Email: cinzia.colapinto@unive.it

${ }^{\ddagger}$ Khalifa University, Department of Industrial \& Systems Engineering, Abu Dhabi, United Arab Emirates. Email: raja.jayaraman@kustar.ac.ae

${ }^{\hat{3}}$ University of Wollongong, School of Accounting, Economics and Finance, Northfields Avenue, Wollongong 2522 NSW, Australia. Email: simonem@uow.edu.au 
importance of the objectives. Polynomial GP (PGP) accommodates the DMs preferences by specifying a polynomial expression for the objective function as the respective deviational variables approaches zero. Aouni et al. (2014) present a comprehensive mathematical treatment of various types of GP models. GP models can incorporate randomness and fuzzy measures in situations where the DM is not sure of the model parameters and the goals. Fuzzy GP models (FGP) were introduced in early 1980s based on fuzzy set theory and have continued to be more popular in recent decades. Ramadan (1997) explores the relationship between GP and fuzzy programming. Chen and Tsai (2001), Aouni et al. (2009) and Li (2012) present details on FGP and its variants. For detailed mathematical treatment and solution we refer the readers to several interesting books and papers on GP models by Saber and Ravindran (1993), Schniederjans (1995), Jones and Tamiz, (2010) and review articles by Lin (1980), Zanakis and Gupta (1985), Romero (1986), Tamiz et.al., (1995, 1998), Aouni and Kettani (2001), Jones and Tamiz (2002), Aouni et al., (2009a, 2009b).

The aim of this paper is to present a state-of-the-art review of GP models with applications to selected areas in engineering, management science and social science that benefits researchers and practitioners. This paper also intends to explore the evolving trends of publications on GP in recent times. The nature of applications spanning GP models is vast and multidisciplinary. Hence the papers are scattered across various journals. The following electronic journal databases: Proquest, Academic Search, EBSCO-Host, Compedex, Emerald, IEEE Explore, Google Scholar, ISI web of knowledge, JSTOR, Ovid, Scopus- Elsevier, Springer Link have been searched to obtain the complete bibliography of literature using keywords such as: "Goal Programming Models", "Multi-criteria Decision Models", "Applications of Goal Programming", "Optimization Models using Goal Programming". We have restricted our search to papers published from year 2000 (for applications in social sciences we have extended the range till the late 70s due to the very limited number of papers found). Wherever necessary we have included historic papers and books that present detailed introduction to specific methods. The search process has resulted in an enormous number of papers including several conference proceedings, dissertations, unpublished works, and books, which have been excluded from further consideration. We have carefully screened them to be inclusive citing all relevant papers. Full text articles have been carefully reviewed for relevance and contribution to the selected domains covered by this review. The papers have been categorized based on the GP model employed and are well presented in tables to aid readers understanding.

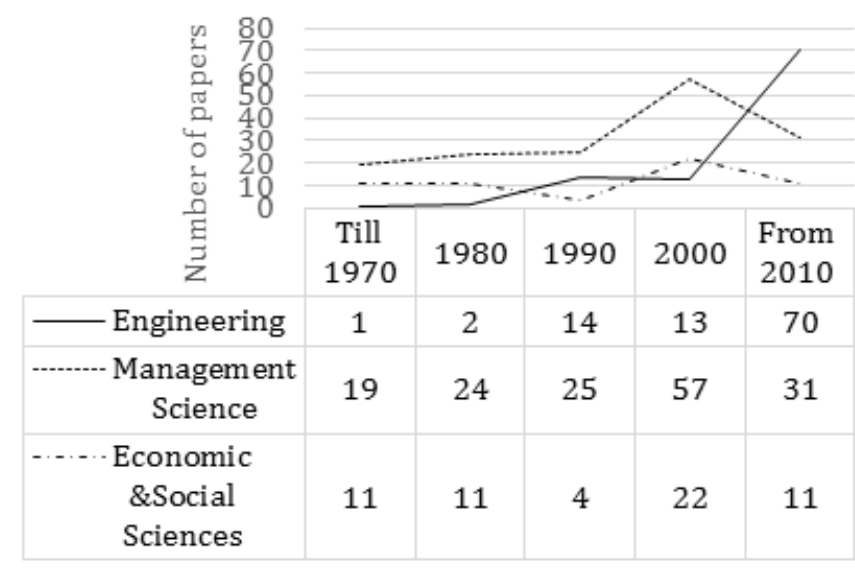

Figure 1: Evolution of goal programming papers in selected disciplines.

Figure 1 shows the evolution of GP models in such three disciplines. It clearly shows that GP applications in engineering were quite limited until 2000s, but the interest in GP in the discipline has substantially increased since 2010. The growth of GP applications in management sciences has been steady until 2010 and since 2010 has received increased attention from researchers. Papers in the area of economics and social sciences were steady until 1980s, with a sudden drop in the number of papers followed by a cyclic pattern of 
increase in 2000s and decrease since 2010 respectively. In comparison to the observation by Schniederjans (1995) on the lifecycle of GP research between 1950s to 1993, the past trend of GP research in the selected disciplines were consistent, yet there is a renewed interest among researchers on GP applications.

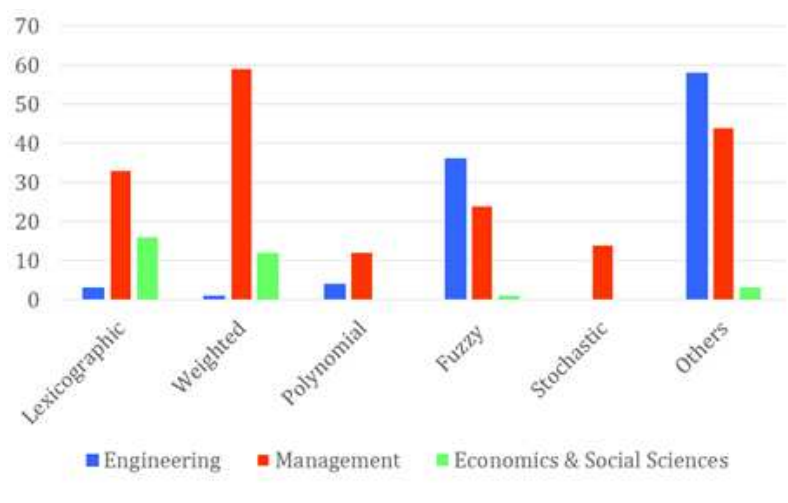

Figure 2: Distribution of various GP models in selected disciplines.

Figure 2 shows the distribution of various GP models in the three disciplines. It is noteworthy that in recent times FGP models have been widely used in both engineering and management science. Lexicographic and weighted models have been well applied to problems in management science, economics and social science.

The paper proceeds as follows. In section 2 we discuss the literature on engineering applications of GP models in supply chain and logistics, manufacturing and production and quality, reliability and maintenance engineering. Section 3 presents the literature on GP models in management science with applications to portfolio selection, marketing and strategic management, while section 4 explores the literature on GP applications in social sciences with particular emphasis on economics. In section 5 we present concluding remarks.

\section{Goal Programming Applications in Engineering}

In this section we discuss engineering applications of GP applied to three important areas: supply chain, logistics and transportation, manufacturing production planning, and quality, reliability and maintenance engineering. We briefly review the papers found in the three identified domains. The papers are categorized according to the employed GP model and the specific field of application (see Table 1).

\subsection{Applications in Supply Chain and Logistics}

Supply chain management involves planning, control and integration in flow of information and materials between suppliers, manufacturers, logistics providers and customers. As products are globally sourced, manufactured and distributed, supply chain management offers several challenging objectives on factors such as cost, inventory, service goals, time to delivery, location and distance that require optimal planning and control. Kongar and Gupta (2000) obtain a unique solution for an integer GP model to determine DM's preferences on allowable tolerance limits of planned and unplanned inventory in a remanufacturing supply chain. Zhou et al. (2000) propose a GP model to address multi-objective problem for a sustainable supply chain optimization and scheduling for a petrochemical plant, the priorities of goals and weights of deviation variables obtained using analytical hierarchy process. Fine at al. (2005) propose a GP modeling approach to address three-dimensional concurrent engineering problems involving product, process and supply chain design applied to automotive supply chains. 


\begin{tabular}{|c|c|c|c|}
\hline GP model & $\begin{array}{l}\text { Supply Chain and Logis- } \\
\text { tics }\end{array}$ & Manufacturing and Production Planning & $\begin{array}{l}\text { Quality, Reliability and } \\
\text { Maintenance }\end{array}$ \\
\hline $\begin{array}{l}\text { Lexicographic } \\
\text { GP }\end{array}$ & & & $\begin{array}{l}\text { Sengupta (1981), Bertolini } \\
\text { and Bevilacqua (2006), } \\
\text { Dowlatshahi (2001) }\end{array}$ \\
\hline $\begin{array}{l}\text { Weighted } \\
\text { GP }\end{array}$ & & Berbel and Rodriguez (1998), & \\
\hline $\begin{array}{l}\text { Polynomial } \\
\text { GP }\end{array}$ & & Alp and Murray (1996), Percin (2006) & Kumar (1985), Tayi (1985) \\
\hline Fuzzy GP & $\begin{array}{l}\text { Amid et al. (2006, 2009, } \\
\text { 2011), Atakan and Ali (2011), } \\
\text { Chin-Nung and Hsing-Pei } \\
\text { (2011), Junyan et al. (2008), } \\
\text { Lee et.al. (2009), Liang } \\
\text { (2007); Selim et al. (2008a); } \\
\text { Selim et al. (2008b), Tien- } \\
\text { Fu (2008), Tsai and Hung } \\
\text { (2009), Zarandi et al. (2011) }\end{array}$ & $\begin{array}{l}\text { Shanker and Vrat (1999), Karsak and Kuzgunkaya } \\
\text { (2002), Rai et al. (2002), Mahapatra and Maiti } \\
\text { (2005), Chan and Swarnkar (2006), Chen and } \\
\text { Weng (2006), Liang (2006), Liang-Hsuan and } \\
\text { Ming-Chu (2006); Mishra et al. (2006), Abouzar } \\
\text { and Mohammad (2009), Chen at al. (2009), } \\
\text { Erol and Ferrell (2009), Ozcan and Toklu (2009), } \\
\text { Torabi and Hassini (2009), Paras et al. (2011), } \\
\text { Taghizadeh et al. (2011), Torabi and Moghad- } \\
\text { dam (2012), Ghasemy et al. (2012), Sadeghi et } \\
\text { al. (2013), Aneirson and Augusto (2014), Kar } \\
\text { (2014), Li and Wan (2014),; Sheikhalishahi and } \\
\text { Torabi (2014) }\end{array}$ & \\
\hline $\begin{array}{l}\text { Other } \\
\text { variants }\end{array}$ & $\begin{array}{l}\text { Schniederjans et al. (1982), } \\
\text { Karpak et al. (1999), Zhou et } \\
\text { al. (2000), Kongar and Gupta } \\
\text { (2001), Ge wang et al. (2004), } \\
\text { Manoj et al. (2004), Charles } \\
\text { et al. (2005), Manoj et } \\
\text { al. (2006), Aktar and Ustun } \\
\text { (2009), Torabi and Hassini } \\
\text { (2009), Liao and Kao (2010), } \\
\text { Songsong and Lazaros (2013), } \\
\text { Mazaher et al., (2014), Nixon } \\
\text { et al. (2014) }\end{array}$ & $\begin{array}{l}\text { Jaaskelainen (1969); Goodman (1974), Lee et al. } \\
\text { (1978); Taylor III at al. (1982), Kendall and } \\
\text { Schniederjans (1985), Han and Ham (1986), Mark- } \\
\text { land and Vickery (1986), Kumar et al. (1987), } \\
\text { Sardana and Vrat (1987); Lee and Jung (1989), } \\
\text { Leong et al. (1989), Shafer and Rogers (1991), } \\
\text { Hoshiono et al. (1995), Kalpic et al., (1995); Le- } \\
\text { ung et al. (2003), Karsak et al. (2003); Yurdakul } \\
\text { (2004), Gokcen and Agpak (2006), Li et al. (2006); } \\
\text { Leung and Ng (2007), Pati et al. (2008), Leung } \\
\text { and Chan (2009), Lin et al. (2009), Satoglu and } \\
\text { Suresh (2009), Liao and Kao (2010), Buyukozkan } \\
\text { and Berkol (2011), Liao (2011), Erdem and Gocen } \\
\text { (2012), Ho et al. (2013), Sharma and Balan (2013) }\end{array}$ & $\begin{array}{l}\text { Hwang et al. (1984), Gen } \\
\text { et al. (1989, 1990, 1993), } \\
\text { Chen (1994), Schnieder- } \\
\text { jans and Karuppan (1995), } \\
\text { Reddy et al., (1997), } \\
\text { Munoz and Ramos (1999), } \\
\text { Badri (2001), Arunraj and } \\
\text { Maiti (2010), Cherif et al. } \\
\text { (2008), Delice and Gungor } \\
\text { (2011), Mariappan et al. } \\
\text { (2011) }\end{array}$ \\
\hline
\end{tabular}

Table 1: Applications of GP models in engineering. 
GP models have been used to study, design and optimize supply chain problems with fuzzy goal programming models as the most popular choice in recent times. FGP permits ambiguous demand and information estimates. An important application of GP in supply chains is the vendor selection problem, dealing with the choice of right vendors and their optimal ordering allocations. Karpak et al. (1999) apply GP techniques to the vendor selection problem; an original equipment manufacturing company copes with competing objectives on appropriate vendors to allocate purchase orders, while minimizing product acquisition costs and maximizing total product quality and delivery reliability. Kumar et al. (2004) discuss solution methods using a FGP model for the vendor selection problem. Wang et al. (2004) use an analytical hierarchy process and LGP based multi-criteria decision-making methodology for supplier selection problem in supply chains. Ghodsypour and O'Brien, (2006) develop a fuzzy multiobjective linear model to overcome the vagueness of goals, constraints and parameters in a vendor selection problem that permits the DM to choose different weights on various objectives. Kumar et al. (2006) formulate a fuzzy multi-objective integer programming for a vendor selection problem incorporating goals related to cost minimization, maximization of quality and on-time-delivery with input parameters using a fuzzy linear membership function.

Ho et al. (2010) present a comprehensive literature survey on multi-criteria decision making approaches for supplier evaluation and selection. Amid et al. (2009) discuss a weighted additive fuzzy multi-objective model for the supplier selection problem that aggregates weighted membership functions of objectives involving minimizing the net cost, net rejected items and net late deliveries, to satisfy capacity and demand constraints. Lee et al. (2009) develop a fuzzy multiple GP model that helps downstream manufacturers to choose thin film transistor liquid crystal display suppliers. Amid et al. (2011) extend Lee et al.'s (2009) model to develop a weighted max-min fuzzy model with different weights; an analytical hierarchy process is used to determine the weights for criteria. Yucel and Guneri (2011) develop a weighted additive fuzzy programming approach using trapezoidal fuzzy numbers to assess the weights of the factors in a fuzzy multiobjective linear model for a vendor selection problem to assign optimum order quantities to each supplier. Liao and Kao (2010) integrate the Taguchi loss function, analytical hierarchy processes and multi-choice GP models for supplier selection problem.

Selim and Ozkarahan (2008a) employ a FGP approach to study supply chain distributor network design model to select the optimum number, location and capacity level of plants and warehouses to deliver products to retailers with least cost to satisfy desired service level. Zhao and Tang (2008) consider quality, budget, and demand as fuzzy variables in an expected value vendor selection model and a fuzzy vendor selection chance constrained programming model to maximize the total quality level in a supply chain. Selim et al. (2008b) propose a FGP approach to solve collaborative production-distribution planning problems under different supply chain structures. Tien-Fu Liang (2008) adopt a fuzzy multi-objective linear programming model with piecewise linear membership functions to solve integrated multi-product and multi-time period production-distribution planning decisions problems with fuzzy objectives. Tsai and Hung (2009) propose a FGP approach to integrate activity-based costing and performance evaluation in a value-chain structure for optimal green supply chain supplier selection and flow allocation. Zardani et al. (2011) extend the work of Selim and Ozkarahan (2008a) using FGP to discuss the role of considering backward parameters in a closed loop supply chain network. Nixon et al. (2014) use GP formulation to model and optimize the supply chain deployment of pyrolysis plant. Schniederjans et al. (1982) present an application of GP to resolve trucking site location problem. Liang (2007) develop a FGP approach for solving the integrated production transportation planning decision problems with fuzzy multiple goals and piecewise linear membership functions to minimize the total distribution and production costs, total number of rejected items, and total delivery time with available capacity, labor level and quota flexibility constraints. Torabi and Hassini (2009) propose a FGP for a multi-objective, multi-site production planning model integrating procurement and distribution plans in a multi-echelon supply chain network.

Additionally, GP models in supply chain have been employed in multi-sourcing decisions and capacity expansion plans. Chin-Nung Liao, Hsing-Pei Kao (2011) propose a fuzzy multi-choice GP model that 
allows DMs to set multiple aspiration levels to solve multi-sourcing supplier selection problems Liu and Papageorgiou (2013) develop a multiobjective mixed-integer linear programming approach with total cost, total flow time and total lost sales as key objectives for expansion of plant capacities in global supply chain, and they propose a solution approach using $\varepsilon$-constraint method and lexicographic method. Recently, Ghorbani et al. (2014) propose a FGP approach for a multi-objective model of reverse supply chain design to minimize recycling cost, rate of waste generated by recyclers and material recovery to design responsive and efficient reverse supply chain.

\subsection{Applications in Manufacturing and Production}

Decision making in manufacturing and production planning environments are critical to the overall output and effectiveness of products and services. With evolving technologies and close integration of suppliers, producers and distributors, mathematical models that use multiple and conflicting objectives are necessary. Jääskeläinen (1969) proposes a GP model with three competing objectives on levels of production, employment and inventories. Goodman (1974) employs a goal programming approach for scheduling aggregate production and work force to conclude that GP models offer effective solutions to aggregate planning problems. Taylor et al. (1982) apply a nonlinear GP model for project and manpower selection encompassing nonlinear relationships among resource utilization and project outcomes.

Kumar et al. (1987) develop a nonlinear GP model for the loading problem in a flexible manufacturing system and obtain the solution through a sequential search approach. Lee and Jung (1989) apply GP method for production planning in a flexible manufacturing system. Cell formation in manufacturing environments encompasses conflicting design objectives relating to set up times, investment, utilization levels, production related goals, etc. Shafer and Rogers (1991) develop a two stage heuristic solution to cell formation problem in a manufacturing environment using GP techniques. Shanker and Vrat (1999) discuss several design issues in cellular manufacturing by comparing multi-objective fuzzy model with their equivalent GP formulation. Karsak and Kuzgunkaya (2002) use fuzzy multiple objective programming approach to facilitate decision making in the selection of flexible manufacturing systems Rai et al. (2002) adopt FGP to model the problem of machine-tool selection and operation allocation with objectives considering minimizing the total cost of machining operation, material handling and set-up. Mishra et al. (2006) use a FGP model for machine-tool selection and operation allocation problem using random search optimization methodology termed "quick converging simulated annealing" which outperforms genetic algorithms and simulated annealing approach. Chan and Swarnkar (2006) develop a FGP approach to model the machine tool selection and operation allocation problem of flexible manufacturing system using ant colony optimization approach. Chen et al. (2009) use a FGP approach to assist machine purchasing decisions for a flexible manufacturing cell.

Hoshino et al. (1995) develop GP techniques to study a recycle-oriented manufacturing system that seeks to satisfy the two objective functions related to total profit and recycling rate. Konger and Gupta (2001) use an integer GP model that provides a unique solution for the allowable inventory level for a remanufacturing supply chain based on the DM's unique preferences to determine the number of components to be kept in the inventory while economically fulfilling the demand of several components, and minimizing waste generation. Goken and Agpak (2006) propose a GP model for the simple U-line balancing problem. Li et al. (2006) develop a GP approach to formulate the early tardiness production planning problem. Liang (2006) study fuzzy multi-objective transportation problems with piecewise linear membership functions to simultaneously minimize the total distribution costs and the total delivery time with reference to available fuzzy supply and total budget at each source, and fuzzy forecast demand and maximum warehouse space at each destination.

Several GP models have been used to study production planning problems. Leung et al. (2003) propose a multi-objective model to solve the production planning problem where profits are maximized and production penalties are minimized for not meeting the quotas and changes in workforce level. Torabi and Moghaddam (20012) propose a multi-objective, multi-site production planning model integrating procurement and distri- 
bution plans in a multi-echelon supply chain network with multiple suppliers, multiple manufacturing plants and multiple distribution centers. An interactive FGP model is developed to simultaneously satisfy the conflicting objectives on minimization of total cost of logistics; defective items, late deliveries and maximization of the total value of purchasing subject to realistic constraints. Torabi and Moghaddam (2012) study a multi-site integrated production-distribution planning problem with transshipment node to accommodate fluctuating and dynamic demands using a FGP model. Leung and Ng (2007) develop a LGP model to solve aggregate production planning for perishable products with three objectives relating to direct production, master production and final assembly that was optimized hierarchically. Pati et al. (2006) formulate a mixed integer GP model to assist management decisions in the paper recycling logistics system.

Karsak et al. (2003) develop a zero-one GP methodology to include importance levels of product technical requirements derived using the analytical network process satisfying the goals on costs, extendibility level and manufacturability level in designing the product. Yurdakul (2004) develops a combined model (analytical hierarchy process and GP) for investment decisions in computer integrated manufacturing. Chen and Weng (2006) propose a FGP model to determine the fulfillment levels of design requirements with fuzzy coefficients in the proposed model to satisfy the goals on customer satisfaction, cost and technical difficulty of design requirements. Lin at al. (2009) propose an interactive meta-goal programming based decision methodology for collaborative manufacturing among small and medium enterprises. Özcan and Toklu (2009) use a LGP model for precise goals and a FGP model for imprecise goals in two-sided assembly line balancing. Satoglu and Suresh (2009) propose a GP model for the design of hybrid cellular manufacturing systems in a resource constrained environment. Jamalnia and Soukhakian (2009) adopt a fuzzy multi-objective nonlinear programming model with different goal priorities for aggregate production planning problem in a fuzzy environment.

Leung and Chan (2009) propose a GP model for aggregate production planning with resource utilization constraint. Taghizadeh et al. (2011) employ an interactive multiple FGP approach to the multi-period multiproduct production planning problem using piecewise linear membership functions to represent satisfaction levels of DMS. Deshpande et al. (2011) propose a model for a single product inventory control of a supply chain consisting of three echelons using FGP approach to model the aspiration levels of the DM Sadeghi et al. (2013) develop a multi-objective model for aggregate planning problem in which the parameters of the model are expressed as grey numbers, and the model is solved as a GP problem with fuzzy aspiration levels. More recently, Francisco da Silva and Marins, (2014) adopt a FGP for an aggregate production planning problem applied to the Brazilian Sugar and Ethanol Milling Company. Sheikhalishahi and Torabi (2014) use a FGP approach for maintenance supplier selection with risk and life cycle costs.

\subsection{Applications in Quality, Reliability and Maintenance Engineering}

Goal programming models have been applied to study a variety of problems relating to quality control and maintenance engineering. Quality control problems can be defined as determining the levels of input and process variables to meet optimal output specifications. The emphasis of quality in both product and service based industries is subject to multiple conflicting objectives on product costs, multiple process variable, process inputs and many other factors. Additionally, production systems are subject to deterioration effects requiring decisions concerning maintenance and resource allocation to ensure system reliability and system availability.

Sengupta (1981) proposes a LGP model to study a multi-objective process control problem for quality control applied to paper manufacturing industry. Tayi (1985) formulates a process quality control problem using linear and PGP problem applied to paper industry to conclude that solutions obtained using the PGP formulation are more conducive for practical interpretations. Gen et al. (1989) develop computational algorithms for solving zero-one GP for optimization problem of system reliability for allocating redundant units. By extending this work, Gen et al. (1990 1993) propose an efficient algorithm for solving large scale 
zero-one problems with generalized upper bounding applied to problems in system reliability. Schniederjans and Karuppan (1995) propose a zero-one type GP model to select quality control attributes for data collection in service organizations. Badri (2001) extends Schniederjans and Karuppan's (1995) work by proposing a combined an analytical hierarchy process and GP model; the quality attributes obtained by the analytical hierarchy process are weighted and solved using a GP model to the choose best set of quality control instruments for data collection in service organizations. Bertolini and Bevilacqua (2006) use a LGP model to define the best strategies for the maintenance of critical centrifugal pumps in an oil refinery. Chen (1994) applies a zero-one GP model for scheduling maintenance activities of mineral processing equipment at a copper mine in China. Cherif et al., (2008) propose two formulations for designing a quality control system based on imprecise GP model with satisfaction functions. Arunraj and Maiti (2010) develop based maintenance policy using a GP model combined with an analytical hierarchy process incorporating the risk of equipment failure and cost of maintenance. Mariappan et al. (2011) develop an optimal preventive maintenance schedule using GP approach.

Hwang et al. (1984) formulate an algorithm for a nonlinear integer GP model using branch and bound techniques to solve reliability problems with multiple objectives. Munoz Moro and Ramos (1999) use GP models to develop a weekly maintenance scheduling for a large scale Spanish power system considering reliability and economic criteria. Reddy et al. (1997) present an approach to optimize multiple responses for quality control using GP in combination with Taguchi's methodology for injection molding process. Dowlatshahi (2001) applies a LGP model to study the role of life cycle costing and time based competition and other goals with respect to decisions on strategic, intermediate and tactical levels. Delice and Güngör (2011) employ a mixed integer GP model to optimize these goals on design requirements of a quality function deployment process.

\section{Goal Programming Applications in Management Science}

Goal programming has a close correspondence with decision making. As managers are constantly called upon to make decisions in order to solve problems, this technique is particularly relevant in the field. Business success relies on effective decision making processes, and GP models can assist. In particular assigned weights can express the intensity with which the goals are strived for. Moreover in management the multiple GP approach can be considered as an extension of the widely used break-even analysis. GP has been applied in different management fields, such as accounting (budgeting, cost allocation, corporate social reporting...), finance (asset management, portfolio selection...), marketing (sales operation, media planning...), operations (inventory management, transportation...) and natural resources. The increasing popularity of GP and usefulness for decision making policies are particularly evident in some areas, such as portfolio management and marketing. For each of these areas we will briefly summarize some of the main applications. This section reviews more than 180 applications found in the management literature, divided in three main areas: portfolio selection, marketing and strategic management. These works, categorized according the used GP model and the specific field of application, are summarized in Table 2.

\subsection{Applications in Portfolio Selection}

Since its origin in early 1950s, portfolio theory has been improved, enlarged, and completed along several directions. Since the 1970s different GP model variants have been applied to the multidimensional financial portfolio selection problem and recently more complex (such as stochastic and fuzzy GP) models have become more and more relevant, due to the fuzzy nature of the data and target levels required by the DM(s).

At the beginning (and till the 1980s) the lexicographic GP is widely applied in financial portfolio selection: its first formulation is provided by Lee (1972). Lee and Lerro (1973) and Sharma and Sharma (2006) apply the LGP for mutual funds highlighting that their model generates good results comparatively to Markowitz 


\begin{tabular}{|c|c|c|c|}
\hline GP Models & Portfolio Selection & Marketing & Strategic Management \\
\hline $\begin{array}{l}\text { Lexicographic } \\
\text { GP }\end{array}$ & $\begin{array}{l}\text { Lee (1972), Lee and Lerro (1973), Kumar } \\
\text { et al. (1978), Muhlemann, et al. (1978), } \\
\text { Booth and Dash (1979), Kumar and Philip- } \\
\text { patos (1979), Lee and Chesser (1980); Levary } \\
\text { and Avery (1984), Alexander and Resnich } \\
\text { (1985), Batson (1989), Colson and De Bruyn } \\
\text { (1989), Sharma and Sharma (2006), Bahloul } \\
\text { and Abid (2013), Tamiz at al. (2013), } \\
\text { Ghahtarani and Najafi (2013) }\end{array}$ & $\begin{array}{l}\text { Seely et al. (1980), Patankar } \\
\text { and Mitra (1989), Brauer and } \\
\text { Naadimuthu (1990), Mitra and } \\
\text { Patankar (1990), Kwak et } \\
\text { al. (1991), Brauer and } \\
\text { Naadimuthu (1992), Lee and } \\
\text { Kwak (1999), Wang and Chin } \\
\text { (2008) }\end{array}$ & $\begin{array}{l}\text { Bottoms and Bartlett (1975), Tay- } \\
\text { lor III and Keown (1978), Chisman } \\
\text { and Rippy (1979), Kao and Brodie } \\
\text { (1979), David and Taylor III (1980), } \\
\text { Seely et al. (1980), Marten and } \\
\text { Sancholuz (1982), Carillo and Jorge } \\
\text { (2006), Verma et al. (2010), Sen and } \\
\text { Nandi (2012) }\end{array}$ \\
\hline $\begin{array}{l}\text { Weighted } \\
\text { GP }\end{array}$ & $\begin{array}{l}\text { Lee and Sevebeck (1971), Callahan (1973), } \\
\text { Kvanli (1980), Sharda and Musser (1986), } \\
\text { Zaloom et al. (1986), O'Leary and O'Leary } \\
\text { (1987), Booth and Bessler (1989), Sharma } \\
\text { et al. (1995), Tamiz et al. (1996), Cooper } \\
\text { et al. (1997), Dominiak (1997), Tamiz et } \\
\text { al. (1997), Kosmidou and Zopounidis (2004), } \\
\text { Pendaraki et al. (2004, 2005), Tektas et al. } \\
\text { (2005), Zopounidis et al. (2005), Bravo et al. } \\
\text { (2010), Tamiz at al. (2013) }\end{array}$ & $\begin{array}{l}\text { Charnes et al. (1968a, 1968b), } \\
\text { Lee (1972), Rifai and Hanna } \\
(1975) \text {, Keown and Duncan } \\
(1979) \text {, Taylor III and An- } \\
\text { derson (1979), Charnes et al. } \\
\text { (1985), Hoffman et al (1996), } \\
\text { Akgunduz et al. (2002), Reyes } \\
\text { and Frazier (2007), Jones et al. } \\
\text { (2007), Iranmanesh and Thom- } \\
\text { son (2008), Wang et al. (2008), } \\
\text { Jha et al. (2011), Chang et al. } \\
\text { (2012a, 2012b), Liao and Chich } \\
\text { (2014), Liu et al. (2014) }\end{array}$ & $\begin{array}{l}\text { Lee and Nicely (1974), Dane et al. } \\
\text { (1977), Keown and Taylor III (1978), } \\
\text { Lee et al.(1979), Bazaraa and Bouza- } \\
\text { her (1981), Sandiford (1986), Hoff- } \\
\text { man and Schniederjans (1990, 1992), } \\
\text { Yura et al. (1994), Gagnon and } \\
\text { Sheu (1997), Gozlu et al. (1999), } \\
\text { Verma and Shrivastava (2000), Zo- } \\
\text { grafos and Oglethorpe (2004), Agha } \\
\text { (2006), Aktar Demirtas and Ustun } \\
\text { (2009), Blancas et al. (2010), Tsai } \\
\text { et al. (2010), Verma et al. (2010), } \\
\text { Tsai and Kuo (2011), Ramanathan } \\
\text { (2012), Ghars et al. (2014), Limanei } \\
\text { et al. (2014) }\end{array}$ \\
\hline $\begin{array}{l}\text { Polynomial } \\
\text { GP }\end{array}$ & $\begin{array}{l}\text { Tayi and Leonard (1988), Lai (1991), Chun- } \\
\text { hachinda et al. (1997), Leung, et al. (2001), } \\
\text { Prakash et al. (2003), Sun and Yan (2003), } \\
\text { Lucey et al. (2004), Canela and Collazo } \\
\text { (2007), Lai et al. (2006), Xu et al. (2007), } \\
\text { Davies et al. (2009), Briec et al. (2013) }\end{array}$ & & \\
\hline Fuzzy GP & $\begin{array}{l}\text { Ignizio (1982), Watada (1997), Inuiguchi and } \\
\text { Ramik (2000), Arenas-Parra et al. (2001), } \\
\text { Wanga and Zhu (2002), Bilbao-Terol et al. } \\
\text { (2006c), Bilbao-Terol et al. (2007), Mansour } \\
\text { et al. (2007), Perez et al. (2007), Sharma et } \\
\text { al. (2009), Gupta and Bhattacharjee (2010), } \\
\text { Kocadaglland Keskin (2014), Trenado (2014) }\end{array}$ & $\begin{array}{l}\text { Tsai et al. (2008), Liao (2011), } \\
\text { Lotfi and Torabi (2011), Tyagi } \\
\text { et al. (2011), Jha and Aggar- } \\
\text { wal (2012), Ghasemi Yaghin et } \\
\text { al. (2013) }\end{array}$ & $\begin{array}{l}\text { Biswas and Pal (2005), Araz et } \\
\text { al. (2007), Sharma et al. (2007), } \\
\text { Khalili-Damghani and Sadi-Nezhad } \\
\text { (2013), Mirkarimi et al. (2013) }\end{array}$ \\
\hline $\begin{array}{l}\text { Stochastic } \\
\text { GP }\end{array}$ & $\begin{array}{l}\text { Aouni et al. (2005), Ballestero (2005), Ji } \\
\text { et al. (2005), Ben Abdelaziz et al. (2007), } \\
\text { Ballestero et al. (2009), Ben Abdelaziz et } \\
\text { al. (2009), Aouni et al. (2010), Aouni et } \\
\text { al. (2012a), Ballestero and Garcia-Bernabeu } \\
\text { (2012), La Torre and Maggis (2012) }\end{array}$ & Aouni et al. (2012b) & $\begin{array}{l}\text { Al-Zahrani and Ahmad (2004), } \\
\text { Aouni et al. (2005), Bravo and } \\
\text { Gonzalez (2009) }\end{array}$ \\
\hline $\begin{array}{l}\text { Other } \\
\text { variants }\end{array}$ & $\begin{array}{l}\text { Stone and Reback (1975), Booth and Dash } \\
\text { (1977), Harrington and Fischer (1980), Muh- } \\
\text { lemann and Lockett (1980), Spronk (1980), } \\
\text { Spronk, (1981), Hallerbach and Spronk } \\
\text { (1986), Spronk and Van Der Wijst (1987), } \\
\text { Konno and Yamazaki (1991), Ballestero and } \\
\text { Romero (1996), Ballestero (1998), Pow- } \\
\text { ell and Premachandra (1998), Jobst et al. } \\
\text { (2001), Allen et al. (2003), Aouni et } \\
\text { al. (2003), Ballestero and Pla-Santamaria } \\
\text { (2003), Rostamy et al.(2003), Ballestero } \\
\text { and Pla-Santamaria (2004), Dash and Ka- } \\
\text { jiji (2005), Deng et al. (2005), Arenas-Parra } \\
\text { et al. (2006), Bilbao-Terol et al. (2006a, } \\
\text { 2006b), Ballestero et al. (2007), Ben Abde- } \\
\text { laziz et al. (2007), Gladish et al. (2007), Li } \\
\text { and Xu (2007), Sharma et al. (2007), Stoyan } \\
\text { and Kwon (2011), Amiri et al. (2011), Aouni } \\
\text { et al. (2013), Tamiz at al. (2013) }\end{array}$ & $\begin{array}{l}\text { De Kluyer (1979), Kwak et al. } \\
\text { (2005), Bhattacharya (2009), } \\
\text { Liao (2009), Paksoy and Chang } \\
\text { (2010), Aouni et al. (2012b) }\end{array}$ & $\begin{array}{l}\text { Lee and Shim (1986), Min and } \\
\text { Melachrinoudis (1996), Schnieder- } \\
\text { jans and Garvin, (1997), Verma and } \\
\text { Shrivastava (2001), Tsai and Chou } \\
\text { (2009), Verma et al. (2010) }\end{array}$ \\
\hline
\end{tabular}

Table 2: Applications of GP models in management science. 
$(1952,1959)$ and Sharpe $(1967)$, as they incorporate the trade-offs between financial risk and inflation risk. Kumar et al. (1978) and Kumar and Philippatos (1979) present a LGP for dual-purposes funds and provide empirical demonstrations to show that dual-purpose funds managers can improve their investment selection and the subsequent performance by relying on the GP methodology. Recently, Bahloul and Abid (2013) introduce a combined analytic hierarchy process and GP approach to international portfolio selection in the presence of some barriers to international investment. Ghahtarani and Najafi (2013) propose a robust optimization model for the portfolio selection problem that uses a LGP approach.

The objective function in the WGP model for portfolio selection seeks to minimize risk and maximize return by penalizing excess risk and shortfalls in return, relative to the respective targets. WGP allows not penalizing lower levels of risk and higher levels of return. The WGP has been applied to the financial portfolio selection problem by Sharma et al. (1995). Then Tamiz et al. (1996) have adapted Lee's (1972) model and specified a WGP formulation for the portfolio selection problem with two stages: $i$ ) prediction of the sensitivity of the shares to specific economic indicators; and ii) selection of the best portfolio based on the financial DM's preferences.

The incorporation of skewness into an investor's decision making process changes the construction of the optimum portfolio in respect to the one formed only under conditions of mean-variance analysis. According to Lai (1991), the polynomial GP model integrates the DM's preferences regarding the skewness of the objective and it is more efficient than the LGP model: indeed the PGP model incorporates investors' preferences in terms of higher moments of the probability distributions of the rates of return, and is computationally simple. Chunhachinda et al. (1997) and Prakash et al. (2003) apply Lai's (1991) PGP model by considering the investor preferences for positive skewness, to find the best portfolio in the international stock markets and in Latin American, US and European capital markets. Canela and Collazo (2007) revise the different PGP formulations proposed by Lai (1991), Chunhachinda et al. (1997), Prakash et al. (2003) and Sun and Yan (2003) based on the fact that these formulations may lead to unfeasible solutions. In their PGP model, Lucey et al. (2004) show the changes in portfolio composition that arise when not only skewness but also gold asset are concerned. Finally Davies et al. (2009) reveal the importance of equity market neutral funds as volatility and kurtosis reducers, and of global macro funds as portfolio skewness enhancers.

When the DM can only give vague and imprecise goal values, he has better to rely on a fuzzy GP formulation. In their paper, Arenas-Parra et al. (2001) consider the criteria return, risk and liquidity as fuzzy terms and they apply a FGP model to 132 Spanish mutual funds. Chen and Tsai (2001) develop a LGP model in a fuzzy framework. Bilbao-Terol et al. (2006c) integrate the knowledge of the expert and the preferences of the DM. They make an extension of Sharpe model where the data are fuzzy and the betas are estimated on the basis of historical data. Mansour et al. (2007) develop an imprecise GP model for portfolio selection based on the satisfaction functions within the Tunisian Stock Exchange market. The financial DM's intuition, experience and judgment are expressed explicitly through the satisfaction functions. Three objectives are considered: rate of return, the liquidity and the risk.

As in many real financial contexts, the DM has to take decisions under uncertainty and the stochastic GP model better deals with the uncertainty related to the decision making situation. Mainly, in the SGP the goal values are stochastic and follow a specific probability distribution. This model has been firstly introduced by Aouni et al. (2005). Ji et al. (2005) develop a linear SGP for multistage portfolio selection. They generate scenarios and they optimize several objectives. In their paper, Ben Abdelaziz et al. (2009) propose a discrete SGP model to generate financial portfolios for the United Arab Emirates equity market considering five objectives, namely capital appreciation, current income, price earnings ratio, market value to the book value ratio and risk. Ballestero et al. (2009) combine the SGP model and the fuzzy logic to formulate a model for portfolio selection problem. This model is applied to the buy-and-hold choice of fund portfolios where several uncertain states of nature are taken into consideration. La Torre and Maggis (2012) consider a SGP model for risk minimization of a financial portfolio managed by an agent subject to different possible criteria and they extend the classical risk minimization model with scalar risk measures 
to the general case of set-valued risk measure. Recently Ballestero and Garcia-Bernabeu (2012) introduce a mean-variance SGP approach to portfolio selection with multiple time horizons. An alternative way to include randomness is to consider the so-called scenario-based models, as introduced in Aouni et al. (2010) in order to analyze portfolio optimization problems and then extended in Aouni et al. (2012a) in the context of venture capital decision making.

It is possible to identify a residual category to include all other GP variants used in portfolio management over the years, including min-max GP, integer GP, compromised programming. The min-max GP model (Romero, 1991:5) falls as much under the subject of linear programming as GP, and it is also known as the model of Chebyshev GP; Deng et al. (2005) present a min-max model on optimal portfolio selection with uncertainty of both randomness and estimation in inputs. A second variant is the nonlinear GP model, as the one used by Stone and Reback (1975) with a focus on risk and dividend goals subject to transaction costs. The integer GP is used to solve the dynamic multiple-objective problem, by Harrington and Fischer (1980) and Muhlemann and Lockett (1980). Other researchers propose mixed-integer GP models (Rostamy et al., 2003; and Aouni et al., 2013). In particular, Stoyan and Kwon (2011) study a stochastic-goal mixed-integer programming approach for integrated stock and bond portfolio optimization. Ballestero and Romero (1996) and Ballestero (1998) are the first to apply the compromised programming model to portfolio selection problem. Arenas-Parra et al. (2006), Bilbao-Terol et al. (2006a, 2006b) and Ballestero et al. (2007) develop a fuzzy compromised programming model where the distance between fuzzy ideal values of the goals and the achievement levels are to be minimized. Amiri et al. (2011) propose a compromised programming method whose results are more consistent with the financial DM's purposes. Aouni et al. (2003) and Ben Abdelaziz et al. (2007) develop a chance constrained compromise programming model for the portfolio selection problem in the Tunisian stock exchange market. The interactive GP models for portfolio management have been used since the 1980s (Spronk 1980, 1981; Gladish et al. 2007). Other alternative applications of GP in the context of portfolio optimization can be found in: Konno and Yamazaki (1991), Jobst et al. (2001), Allen et al. (2003), and Sharma et al. (2007).

\subsection{Applications in Marketing}

Marketing decisions have to be carefully analyzed as they affect all other functional activities and contribute at every level in the company's hierarchy of goals. GP has been implemented in several contexts of marketing research, from strategic marketing issues (Lee and Nicely (1974) to more specific issues: distribution decisions (Kwak, et al., 1991); marketing and quality control (Sengupta, 1981), interfunctional coordination or tradeoff decision; just to name a few.In this area the multi-choice GP model is popular as it allows the righthand-side of each goal to be varied among two or more aspiration levels. With multi-choice GP, a DM can consider multiple levels of aspired target values for each goal (see Chang et al., 2012a, 2012b). Following the core spirit of multi-choice GP, in the multi-segment GP model, the coefficient on the left-hand-side allows the DM to set multiple segments of a coefficient on the left-hand-side for decision variables.

Another active area of marketing applications is related to media planning: GP (Charnes, et al., 1985; Charnes and Reinecke, 1968; De Kluyver, 1979) is used as a tool to allocate advertising appropriations to various media (media scheduling/selection). The media planning function includes the selection of advertising media, as well as the development and allocation of the advertising budget. Charnes et al. (1968) utilize the GP model for media planning: he incorporates the concept of market segmentation and the time component; and uses the frequency distribution instead of the customary single value for average frequency with the audience duplication accounted for. Keown and Duncan (1979) propose a model which improves on linear programming by successfully providing optimal, integer solutions that more realistically reflect the complexity of the media decision environment. De Kluyver (1979) introduce min-sum and min-max GP models that are enriched by the use of "soft" constraints, forcing searches in the feasible region in predetermined directions, and hence easing the task of analyzing alternatives. Bhattacharya (2009) proposes a 
chance constrained GP model that has been formulated in such a way that the advertisement should reach those who are suitable for the product instead of going to those section that are not considered suitable for the product as well. Jha et al. (2011) include the practical aspect of segmentation and develop a model which deals with optimal allocation of advertising budget for multiple products which is advertised through different media in a segmented market. Also due weightages are given to various media so as to maximize the total advertising effectiveness.

Many researchers focus on the need for greater coordination and integration between marketing and other functions (such as manufacturing, R\&D, and finance) because of the interactions and conflicts occurring in a firm. Taylor III and Anderson (1979), and Decro (1984) develop a GP model for dealing with the complex trade-off decisions involved in marketing/production planning. Yaghin et al. (2013) propose an FGP model in order to consider pricing, marketing and lot-sizing decisions simultaneously. Some papers focus on specific marketing issues, like distribution planning (Brauer and Naadimuthu, 1990; Kwak et al., 1991), and shelf space allocation (Reyes and Frazier, 2007).

GP has also been widely applied for production planning decision making. Liu et al. (2014) deal with product family design using analytic network process and GP techniques able to reduce design expenses and enhance efficiency through reusing component designs and extending product portfolio. Marketing decision making such as price discrimination, customer segment, time segment, location and channel segment designs are often formulated as multi-segment aspiration level problems; Liao (2009) proposes a method for solving this multi-segment GP problem. Jones et al. (2007) show that GP is a flexible tool suitable for forming pattern classification models: they test the model on a real-life dataset pertaining to cinema-going attendance.

\subsection{Applications in Strategic Management}

Strategic decision making is an ongoing process that involves creating strategies to achieve goals and altering strategies based on observed outcomes. There exist many tools and models that managers can use in many situations. Keown and Taylor III (1978) present an integer goal programming model able to provide the management with an additional decision making tool for the implementation of multiple corporate objectives. GP has been proved to be a useful tool also for small businesses: Lee and Shim (1986) present an interactive GP model starting on the original work by Lee et al. (1979). One of the most critical strategic decisions facing managers industry concerns the global expansion of operations. Hoffman and Schniederjans (1990, 1992) present a multi-objective model (a zero-one GP model) using critical success factors as a basis for international business expansion analysis. Other important areas in which strategic management plays a fundamental role deal with natural resources and tourism.

Multicriteria methodologies represent an interesting tool to integrate qualitative and quantitative approaches to study environmental and natural resource management problems (Edwards-Jones et al., 2000), thus they have been quite extensively utilized in the field. One of the first study in this framework can be found in Bottoms and Bartlett (1975), who study the impacts on lands and its derived products of different management alternatives in the Colorado State Forest; they propose a LGP model, focusing both on goals product-oriented (different animals months of grazing, recreation user days of camping, board feet of different vegetation) and non-product oriented (profits, sediments). Early studies applying LGP include Chisman and Rippy (1979), Kao and Brodie (1979), and Marten and Sancholuz (1982), while those applying WGP include Dane et al. (1977), Bazaraa and Bouzaher (1981), and Sandiford (1986). Several reviews have been published over the last decades to survey applications of GP in the natural resource management field; among others, a discussion of earlier works can be found in Romero and Rehman (1987) while discussions of more recent studies can be found in Steiguer et al. (2003) and Mendoza and Martins (2006). We thus restrict our discussion to applications published over the last ten years or so. Most recent applications can be classified into two main areas: cropping and water management. Works in the former category try to 
assess the impact of alternative cropping products or techniques in specific regions or case studies. Biswas and Pal (2005) propose a FGP model to study the land use planning problems in an agricultural setup in a district of the West Bengal area in India. They focus on the impact of alternative cropping plans on economic (cash expenditure, production achievement, profit) and land-oriented (land utilization, productive resource) goals. Similar approaches based on FGP applications in India and Iran can be found in Sharma et al. (2007) and Mirkarimi et al. (2013), respectively. Simpler models focusing on the same region include LGP (Sen and Nandi, 2012) and WGP (Limanei et al., 2014) models. Another active area of research deals with water management problems. Verma et al. (2010) present an application of different (lexicographic, weighted, min-max) GP techniques to analyze optimal monthly operation in a system of reservoir in India. They show that LGP models, since imposing a clear-cut among priorities, allow optimizing water resource systems more efficiently. The same case study is analyzed also in Verma and Shrivastava (2000, 2001) who develop a weighted and min-max GP approach, respectively. Other applications in the field include stochastic (Al-Zahrani and Ahmad, 2004; Aouni et al., 2005; and Bravo and Gonzalez, 2009) and integer GP (Agha, 2006) models.

Since the late 1970s the potential usage of operational research techniques to study tourism problems, like the determination of tourist flows or the evaluation of the impact of tourism activities, has been very well known (Swart et al., 1978). However, applications of GP techniques in this field are quite limited, and they can be grouped in two main areas: tourism planning and sustainable tourism. Studies in the former area are quite dated and try to understand how alternative tourism strategies might impact the eventual success of a tourism destination. Taylor III and Keown (1978) propose an integer GP model in order to select in which specific sites within the city boundaries to develop recreational facilities, by taking into account financial, spatial and land resources availability. Seely et al. (1980) develop a LGP model to identify the optimal allocation of public funds among different marketing programs in order to achieve the greatest impact (measured at different levels); their study focuses on the United States Travel Service as a case study to test the effectiveness of their model. Similarly, David and Taylor III (1980) rely on LGP model to study the allocation of promotional efforts in the US by also taking into account income, travel propensity, gravitational and demographic variables. Works in the latter area are instead more recent and they link the analysis of alternative tourism strategies to the problem of sustainable development. Zografos and Oglethorpe (2004), by borrowing from the natural resource management literature, use a WGP model to assess sustainable solutions related to ecotourism activities in the Amazonian rainforest in Ecuador. They aim at identifying the impact of ecotourism and other potential activities on the sustainability of the local community's development; they focus on economic, social and environmental goals, showing that ecotourism might cease to be an optimal land use only if the weight attached to private income increases significantly with respect to the other goals. Carillo and Jorge (2006) further analyze the trade-off between tourism development and environmental exploitation by proposing a LGP model to quantify the tourism carrying capacity of a specific destination. They analyze both the positive economic (total outlays) and negative environmental (waste disposal) impacts of tourism activities generated by different types of visitors in Venice (Italy). Blancas et al. (2010) underline how making sustainability-related decisions in the field of tourism is particularly difficult since reliable information is to a large extent missing; their work develops along this direction by proposing a synthetic sustainability indicator based on a WGP approach to support the decision making process.

\section{Goal Programming Applications in Social Sciences}

Applications of goal programming in social sciences are not as diffused as in other disciplines, and they are limited in scope and sporadic in nature. Among social sciences, the discipline presenting the largest number of works is definitely economics, very few are those in demography (Stern, 1974) and geography (McGrew, 1975) while no study at all can be found in political science. In this section we thus limit our review to 
applications in economics. Most of the papers analyzed in this review apply the simplest (lexicographic, weighted, max-min and integer) GP models, only one employ a fuzzy model while none rely on polynomial or stochastic approaches. This probably reflects the weaker training that social scientists generally receive in mathematical and computational techniques with respect to researchers working in engineering and management disciplines. This section briefly reviews about 30 applications found in economics from the early 1970s to today. These works, categorized according the used GP model and the specific field of application are summarized in Table 3 .

\begin{tabular}{|c|c|c|c|c|c|}
\hline GP model & $\begin{array}{l}\text { Provision of public } \\
\text { goods }\end{array}$ & $\begin{array}{l}\text { Environmental inter- } \\
\text { actions }\end{array}$ & $\begin{array}{l}\text { Macroeconomic } \\
\text { policies }\end{array}$ & Other economics & $\begin{array}{l}\text { Other } \\
\text { social } \\
\text { sciences }\end{array}$ \\
\hline $\begin{array}{l}\text { Lexicographic } \\
\text { GP }\end{array}$ & $\begin{array}{l}\text { Lee and Clayton (1972), } \\
\text { Schroeder (1974), Ke- } \\
\text { own and Martin (1976), } \\
\text { Tingley and Liebman } \\
\text { (1984), Diminnie and } \\
\text { Kwak (1986), Kwak and } \\
\text { Diminnie (1987), Ri- } \\
\text { fai and Pecenka (1989), } \\
\text { Blake et al. (2002) }\end{array}$ & & André et al. (2009) & $\begin{array}{l}\text { Arthur and Ravin- } \\
\text { dran (1981), Ozkara- } \\
\text { han and Bailey } \\
(1988), \quad \text { Baykasoglu } \\
(2001), \quad \text { Leung and } \\
\mathrm{Ng}(2007) \text {, Leung and } \\
\text { Chan (2009), Jenal et } \\
\text { al. (2011) }\end{array}$ & $\begin{array}{l}\text { McGrew } \\
(1975)\end{array}$ \\
\hline $\begin{array}{l}\text { Weighted } \\
\text { GP }\end{array}$ & $\begin{array}{l}\text { Taplin et al. (1995a), } \\
\text { Taplin et al. (1995b) }\end{array}$ & $\begin{array}{l}\text { Goicoechea and Stakhiv } \\
(1992), \text { Hobbs et al. } \\
(1992), \quad \text { Linares and } \\
\text { Romero (2000), Bell et } \\
\text { al. (2001), Linares and } \\
\text { Romero (2002) }\end{array}$ & $\begin{array}{ll}\text { Schinnar } & (1976), \\
\text { André et al. } & (2009), \\
\text { Colapinto et al. } \\
(2014)\end{array}$ & $\begin{array}{l}\text { Azaiez and Al Sharif } \\
(2005)\end{array}$ & $\begin{array}{l}\text { Stern } \\
(1974)\end{array}$ \\
\hline \multicolumn{6}{|l|}{$\begin{array}{l}\text { Polynomial } \\
\text { GP }\end{array}$} \\
\hline Fuzzy GP & & & & Sadeghi et al. (2013) & \\
\hline \multicolumn{6}{|l|}{$\begin{array}{l}\text { Stochastic } \\
\text { GP }\end{array}$} \\
\hline $\begin{array}{ll}\text { Other } & \text { GP } \\
\text { variants }\end{array}$ & Hassan and Loon (2012) & & André et al. (2009) & $\begin{array}{l}\text { Topaloglu and } \\
\text { Ozkarehan (2004) }\end{array}$ & \\
\hline
\end{tabular}

Table 3: Applications of GP models in economics and other social sciences.

\subsection{Applications in Economics}

Applications of GP in economics are abundant. Probably the first study can be identified in Schinnar (1976), who analyzes development planning in a Leontief input-output model; in order to take into account both economic and demographic goals (along with their potential interactions) his study develops a WGP model. After this pioneering work, following studies can be classified into four main areas: public choice, provision of public goods, environmental interactions and macroeconomic policies.

The former area focuses mainly on group decision making which by definition requires the search of some degree of consensus; GP is one of the tools frequently used to support such a collective decision making process. Since GP applications in the field are very numerous and have been recently surveyed we will not discuss such a branch of literature: the interested reader is invited to refer to Munro and Aouni (2009) and references therein.

An active area of research involves the study of the public goods and services' provision, and in particular the appraisal of different public policies. In this context, GP techniques have been proposed as an alternative or an integration of cost-benefit analysis, which is traditionally used in order to assess the net (economic, social, cultural and environmental) value of competing programs. Most of the studies focus on transport (Taplin et al., 1995a, 1995b), health (Blake et al., 2002) and knowledge (Diminnie and Kwak, 1986). In order to assess the potential effects of transport policies Taplin et al. (1995a) employ a WGP model to determine the optimal allocation of public funds among alternative road projects in the Pilbara region of Western 
Australia. They analyze several road projects and goals (classified as road user and supplier, developmental, environmental, level of service, and social). A similar analysis of road projects in the same region can be found in Taplin et al. (1995b) who move the focus on their study on the scheduling of these projects. Several works have tried to study the impact of different health programs: early studies focus on two topics, resource allocation and capital budgeting decisions in public hospitals, employing lexicographic (Rifai and Pecenka, 1989) and integer (Keown and Martin, 1976; Tingley and Liebman, 1984) GP models, respectively. A more recent analysis can be found in Blake et al. (2002) who proposes two alternative LGP models (based on fixed costs and fixed volumes, respectively) to take into account both the goals of the hospital to recoup its costs of production and those of physicians to achieve an acceptable income level; the results are illustrated through a case study focusing on a surgical division of a public hospital in Ontario (Canada). The works analyzing the impact of knowledge dissemination focus on budgeting at university level to exemplify the nature of the problem. For example, Diminnie and Kwak (1986) and Kwak and Diminnie (1987) develop an integer GP model to select among budget alternatives and assess the effect of a shrinking budget situation on both academic and budgeting goals. Other earlier works on university budget planning include Lee and Clayton (1972), and Schroeder (1974) while a more recent study can be found in Hassan and Loon (2012).

Another topic widely analyzed in economics is related to the economic and environmental interactions. In this framework we can identify two main areas of research: the impact of externality and the assessment of GP techniques as a methodological tool. Works in the former area aim at quantifying the magnitude (and its associated cost) of environmental externalities generated by alternative policies. Linares and Romero (2000) use a WGP model to study the impact of several electricity production plans in Spain on economic (cost) and environmental (radioactive waste, and emissions of $\mathrm{CO}_{2}, \mathrm{SO}_{2}$ and $\mathrm{NO}_{x}$ ) goals. Linares and Romero (2002) refine this kind of analysis by proposing a WGP model to aggregate preferences over different goals of four social groups (regulators, academics, electric utilities and environmentalists) with conflicting interests. Bell et al. (2001) develop a WGP model to study the effect of seven global climate policy alternatives; they focus on the same economic goal as in Linares and Romero (2000) but consider a broader variety of environmental goals (including also global temperature increase, sea-level rise, and ecosystem stress). Studies in the assessment of GP techniques area are to a largest extent methodological and try to identify the pros and cons of different GP approaches to assess environmental policies. For example, Hobbs et al. (1992) consider different WGP models to evaluate the level of understanding of multicriteria methods among water planners from the US Army Corps of Engineers. A similar experiment based on the same case study can be found in Goicoechea et al. (1992).

The most recent and probably promising line of research analyzes the impact of macroeconomic policies on traditional economic goals, and in particular it focuses on their linkage to sustainable development by analyzing the economic and environmental trade-off. André et al. (2009) consider different (lexicographic, weighted and max-min) GP models to study the impact of alternative policy tools (direct and indirect taxes, environmental taxes and public expenditure) on both macroeconomic (economic growth, inflation, unemployment, public deficit) and environmental $\left(\mathrm{CO}_{2}, \mathrm{NO}_{x}\right.$ and $\mathrm{SO}_{x}$ emissions) goals; the model is then tested trough an application to the Spanish economy. Colapinto et al. (2014) propose a WGP model with satisfaction function to analyze the nature of the intergenerational equity and sustainable development relationship; they consider two goals (the sum of discounted finite-time utilities and an asymptotic utility level), to understand to what extent DMs can achieve their aim of maximizing social welfare by exploiting natural resources in the short run without compromising the ability of the society to enjoy them in the long run.

Apart from these four main areas of applications in economics, GP techniques have been extensively employed also to study several other economic problems from an engineering perspective, especially those related to production and scheduling activities (a more detailed analysis of these works can be found in section 2, where we discuss applications in engineering). Recent works in the former area focus on aggregate production planning problems, which deal with capacity planning over a short run planning horizon (Bayka- 
soglu, 2001). Leung and Ng (2007) propose a LGP approach to analyze the case of perishable products, which because of their specific nature, require to take into account also inventory goals other than standard goals like those related to costs and layoffs. A LGP model is also used by Leung and Chan (2009) to include resource utilization constraints. Sadeghi et al. (2013) introduce a FGP model in order to extend the analysis to situations of uncertainty as defined by the grey theory. The first works on scheduling go back to the 1980s and aim at identifying the optimal nurse schedules through GP techniques (Arthur and Ravindran, 1981; Ozkarahan and Bailey, 1988); more recent works employ integer GP models (Azaiez and Al Sharif, 2005; Jenal et al., 2011). Topaloglu and Ozkarehan (2004) instead propose an implicit GP model to take into account also preferences of employees, such that the feasible schedules are neither identified by an integer variable nor the employees are asked to quantify their individual preferences for different schedules.

\section{Conclusions}

Goal programming is a well-known and very popular tool used to analyze multi-criteria problems. Over the last 50 years the development and refinement of GP techniques have been impressive, leading GP to be one of the most preferred tools for dealing with multiple criteria decision analysis. Its range of applications is extremely large, including also engineering, management and social sciences. This paper aims at presenting a broad survey of the extensive applications of GP models in these fields, encompassing historic and pioneering papers as well as more recent works. From our survey of more than 300 published papers and from the recent increase (especially in engineering and management disciplines) of the number of applications of GP techniques, it seems clear that the ability to rely on GP approaches nowadays is valued more highly than ever. The growth of GP is beyond all doubt, since publications have continued to increase since the 1970s. In particular, the growth of papers dealing with nonlinear problems has been very significant as well, reflecting the diffusion of more and more complex GP models, such as SGP, FGP or chance constrained GP models. One of its characteristics allowing for such a massive development is the ability of GP to easily combine with other approaches: for instance GP models combined with analytical hierarchy process are commonly applied to different fields (supply chain and logistics, manufacturing and production or portfolio management) and problems successfully. We wish this review provides useful references for researchers willing to extend GP techniques and practitioners wishing to apply GP models to practical problem situations.

\section{References}

1. Abouzar, J., \& Soukhakian, M.A. (2009). A hybrid fuzzy goal programming approach with different goal priorities to aggregate production planning. Computers $\&$ Industrial Engineering, 56(4), 14741486 .

2. Agha, S.R. (2006). Use of goal programming \& integer programming for water quality management a case study of Gaza Strip. European Journal of Operational Research 174, 1991-1998.

3. Akgunduz, A., Zetu, D., Banerjee, P. \& Liang, D. (2002). Evaluation of sub-component alternatives in product design processes, Robotics and Computer Integrated Manufacturing, 18, 69-81.

4. Aktar D. E, \& Ustun, O. (2009). Analytic network process and multi-period goal programming integration in purchasing decisions, Computers $\&$ Industrial Engineering 56(2), 677-690.

5. Alexander, G., \& Resnick, B. (1985). Using linear and goal programming to immunize bond portfolios. Journal of Banking $\&$ Finance, 9, 35-54.

6. Allen, J., Bhattacharya, S., \& Smarandache, F. (2003). Fuzziness and funds allocation in portfolio optimisation. International Journal of Social Economics, 30(5), 619-632.

7. Alp, N., \& Murray, S. L. (1996). A goal programming model to evaluate the production decision through the productivity of sub-systems. Computers $\&$ industrial engineering, 31(1), 363-366. 
8. Al-Zahrani, M.A., \& Ahmad, A.M. (2004). Stochastic goal programming model for optimal blending of desalinated water with groundwater. Journal of Water Resources Management 18, 339-352

9. Amid, A., Ghodsypour, S. H., \& O'Brien, C. (2009). A weighted additive fuzzy multiobjective model for the supplier selection problem under price breaks in a supply chain. International Journal of Production Economics, $121(2), 323-332$.

10. Amid, S.H. Ghodsypour, C. O'Brien, (2006). Fuzzy multiobjective linear model for supplier selection in a supply chain, International Journal of Production Economics, 104(2):394-407

11. Amid, Ghodsypour, S.H., O'Brien, C. (2011). A weighted max-min model for fuzzy multi-objective supplier selection in a supply chain. International Journal of Production Economics, 131(1), 139-145.

12. Amiri, M., Ekhtiari, M. \& Yazdani, M. (2011). Nadir compromise programming: A model for optimization of multi-objective portfolio problem. Expert Systems with Applications, 38, 7222-7226.

13. André, F.J., Cardenete, M.A., \& Romero, C. (2009). A goal programming approach for a joint design of macroeconomic and environmental policies: a methodological proposal and an application to the Spanish economy. Environmental Management 43, 888-898

14. Aneirson Francisco da Silva \& Fernando Augusto Silva Marins, (2014). A Fuzzy Goal Programming Model for Solving Aggregate Production-Planning Problems under uncertainty: A Case Study in a Brazilian Sugar Mill. Energy Economics

15. Aouni A., Ben Abdelaziz, F., \& La Torre, D. (2012a). The Stochastic Goal Programming Model: Theory \& Applications. Journal of Multicriteria Decision Analysis, 19(5-6), 185-200.

16. Aouni B., Colapinto C., \& La Torre D. (2012b) Stochastic goal programming model and satisfaction functions for media selection and planning problem. International Journal of Multicriteria Decision Making, 2, 391-407.

17. Aouni, A., Colapinto, C., \& La Torre, D. (2010a). Solving Stochastic Multi-Objective Programming in Multi-Attribute Portfolio Selection through the Goal Programming Model. Journal of Financial Decision Making, 6(2), 17-30.

18. Aouni, B., (2010b). Portfolio Selection through the Goal Programming Model: An Overview. Journal of Financial Decision Making, 6(2), 3-15.

19. Aouni, A., Colapinto, C., \& La Torre, D. (2013). A cardinality constrained stochastic goal programming model with satisfaction function for venture capital investment decision making. Annals of Operations Research, 205(1), 77-88.

20. Aouni, B. (2009c). Multi-Attribute Portfolio Selection: New Perspectives, Information Systems and Operational Research, 47(1), 1-4.

21. Aouni, B., Ben Abdelaziz, F., \& El Fayedh, R. (2003). La programmation par but stochastique: application au problème de sélection de portefeuille (Stochastic programming: an application to the portfolio selection). Administrative Sciences Association of Canada, Management Science, 24 (2), 63-75.

22. Aouni, B., Ben Abdelaziz, F., \& Martel, J.M. (2005a). Decision-maker's preferences modeling in the stochastic goal programming. European Journal of Operational Research 162, 610-618.

23. Aouni, B., Ben Abdelaziz, F., \& Martel, J.M. (2005b). Decision-maker's preferences modelling in the stochastic goal programming, European Journal of Operational Research 162, 610-618

24. Aouni, B. \& Kettani, O. (2001). Goal programming model: a glorious history and a promising future, European Journal of Operational Research, 133, 225-231.

25. Aouni, B., Hassaine, A., \& Martel, J. (2009a). Decision-maker's preferences modelling within the goalprogramming model: a new typology. Journal of Multi-Criteria Decision Analysis, 16(5-6), 163-178.

26. Aouni, B., Martel, J. M., \& Hassaine, A. (2009b). Fuzzy goal programming model: an overview of the current state-of-the art. Journal of Multi-Criteria Decision Analysis, 16(5-6), 149-161. 
27. Aouni, B., Colapinto, C., \& La Torre, D. (2014). Financial portfolio management through the goal programming model: Current state-of-the-art. European Journal of Operational Research, 234(2), 536545.

28. Araz C., Ozfirat P. M., \& Ozkarahan, I. (2007). An integrated multicriteria decision-making methodology for outsourcing management. Computers $\&$ Operations Research 34(12), 3738-3756.

29. Arditti, F.D. \& Levy, H. (1975). Portfolio Efficiency Analysis in Three Moments: The Multi Period Case. Journal of Finance, 30, 797-809.

30. Arenas-Parra, M., Bilbao-Terol, A., \& Rodriguez Uria, M. V. (2001). A Fuzzy Goal Programming Approach to Portfolio Selection. European Journal of Operational Research, 133, 287-297.

31. Arenas-Parra, M., Bilbao-Terol, A., Rodriguez Uria, M. V., \& Pérez-Gladish, B. (2006). Fuzzy compromise programming for portfolio selection. Applied Mathematics and Computation, 173, 251-264.

32. Arthur, J.L., \& Ravindran, A. (1981). A multiple objective nurse scheduling model, AIIE Transactions $13,55-60$

33. Arunraj, N. S., \& Maiti, J. (2010). Risk-based maintenance policy selection using AHP and goal programming. Safety science, 48(2), 238-247.

34. Atakan Y., \& Güneri, A. F. (2011). A weighted additive fuzzy programming approach for multi-criteria supplier selection, Expert Systems with Applications, 38(5), 6281-6286

35. Azaiez, M.N. \& Al Sharif, S.S. (2005). A 0-1 goal programming model for nurse scheduling, Computers \& Operations Research 32, 491-507

36. Azmi, R. \& Tamiz, M. (2010). A review of goal programming for portfolio selection. In D. Jones, M. Tamiz, \& J. Ries (Eds), New Developments in Multiple Objective and Goal Programming, Lecture Notes in Economics and Mathematical Systems 638, Springer, pp. 15-34.

37. Badri, M. A. (2001). A combined AHP-GP model for quality control systems. International Journal of Production Economics, $72(1), 27-40$.

38. Bahloul, S., \& Abid, F. (2013). A combined analytic hierarchy process and goal programming approach to international portfolio selection in the presence of investment barriers. International Journal of Multi-criteria Decision Making, 3(1), 1-20.

39. Ballestero, E. (1998). Approximating the optimum portfolio for an investor with particular preferences. Journal of Operational Research Society, 49, 998-1000.

40. Ballestero, E., \& Garcia-Bernabeu, A. (2012). Portfolio selection with multiple time horizons: A mean variance - stochastic goal programming approach, preprint.

41. Ballestero, E., \& Pla-Santamaria, D. (2003). Portfolio selection on the Madrid Exchange: A compromise programming model. International Transactions in Operational Research, 10, 33-51.

42. Ballestero, E., \& Pla-Santamaria, D. (2004). Selecting Portfolios for Mutual Funds. Omega, 32, 385-394.

43. Ballestero, E., \& Romero, C. (1996). Portfolio Selection, A Compromise Programming Solution. Journal of the Operational Research Society, 47, 1377-1386.

44. Ballestero, E., Günther, M., Pla-Santamaria, D., \& Stummer, C. (2007). Portfolio selection under Strict Uncertainty: A Multi-Criteria Methodology and its Application to the Frankfurt and Vienna Stock Exchange. European Journal of Operational Research, 181(3), 1476-1487

45. Ballestero, E., Pérez-Gladish, B., Arenas-Parra, M., \& Bilbao-Terol, A. (2009). Selecting Portfolios Given Multiple Eurostoxx-Based Uncertainty Scenarios: A Stochastic Goal Programming Approach from Fuzzy Betas. Information Systems and Operational Research, 47(1), 59-70.

46. Batson, R. G. (1989). Financial Planning Using Goal Programming. Long Range Planning, 22 (5), $112-120$. 
47. Baykasoglu, A. (2001). MOAPPS 1.0: aggregate production planning using the multiple-objective tabu search. International Journal of Production Research 39, 3685-3702

48. Bazaraa,M.S. \& Bouzaher, A. (1981). A linear goal programming model for developing economies with an illustration from the agricultural sector in Egypt, Management Science 27, 396-413

49. Bell, M.L., Hobbs, B.F., Elliott, E.M., Ellis, H., \& Robinson, Z. (2001). An evaluation of multicriteria methods in integrated assessment of climate policy Journal of Multicriteria Decision Analysis 10, 229-256

50. Bellman, R. E., \& Zadeh, L. A. (1970). Decision-Making in a Fuzzy Environment. Management Science, 17, B141-B164.

51. Ben Abdelaziz, F., Aouni, B., \& El Fayedh, R. (2007). Multi-Objective Stochastic Programming for Portfolio Selection. European Journal of Operational Research, 177, 1811-1823.

52. Ben Abdelaziz, F., El Fayedh, R., \& Rao, A. (2009). A Discrete Stochastic Goal Program for Portfolio Selection: The Case of United Arab Emirates Equity Market. Information Systems and Operational Research, 47, 5-13.

53. Berbel, J., \& Rodriguez-Ocana, A. (1998). An MCDM approach to production analysis: An application to irrigated farms in Southern Spain. European Journal of Operational Research, 107(1), 108-118.

54. Bertolini, M., \& Bevilacqua, M. (2006). A combined goal programming-AHP approach to maintenance selection problem. Reliability Engineering 85 System Safety, 91 (7), 839-848.

55. Bhattacharya U.,K., (2009). A chance constraints goal programming model for the advertising planning problem. European Journal of Operational Research 192(2), 382-395.

56. Bilbao-Terol, A., Pérez-Gladish, B., Arenas-Parra, M., \& Rodrìguez Urìa, M.V. (2006a). Fuzzy compromise programming for portfolio selection. Applied Mathematics and Computation, 173 (1), 251-264.

57. Bilbao-Terol, A., Pérez-Gladish, B., \& Antomil-Ibias, J. (2006b). Selecting the optimum portfolio using fuzzy compromise programming and Sharpe's single-index model. Applied Mathematics $\&$ Computation, 182 (1), 644-664.

58. Bilbao-Terol, A., Arenas-Parra, M., Jiménez, M., Pérez-Gladish, B., \& Rodrìguez Urìa, M.V. (2006c). An extension of Sharpe's single-index model: portfolio selection with expert betas. Journal of the Operational Research Society, 57, 1442-1451.

59. Bilbao-Terol, A., Arenas-Parra, M., Rodriguez, M.V., \& Antomil, J. (2007). On constructing expert betas for single-index model. European Journal of Operational Research, 183 (2), 827-847.

60. Biswas, A., \& Pal, B.B. (2005). Application of fuzzy goal programming technique to land use planning in agricultural system. Omega 33, 391-398

61. Blake J.T., \& Carter, M.W. (2002). A goal programming approach to strategic resource allocation in acute care hospitals European Journal of Operational Research 140, 541-561

62. Blancas, F.J., Caballero, R., Gonzalez, M., Lozano-Oyola, \& M., Perez, F. (2010). Goal programming synthetic indicators: an application for sustainable tourism in Andalusian coastal counties Ecological Economics 69, 2158-2172

63. Booth, C.G. \& Bessler, W. (1989). Goal Programming models for managing interest rate risk. Omega, 17, 81-89.

64. Booth, G., \& Dash, G. (1977) Bank portfolio management using non-linear goal programming. Financial Review, 14, 59-69.

65. Booth, G., \& Dash, G. (1979). Alternate programming structures for bank portfolios. Journal of Banking \& Finance, 3(1), 67-82.

66. Bottoms, K.E., \& Bartlett, E.T. (1975). Resource allocation through goal programming, Journal of Range Management 28, 442-447 
67. Brauer, D. C. \& Naadimuthu, G. (1990), A Goal Programming model for aggregate inventory and distribution planning. Math. Comput. Modelling, 14, 1085-1090.

68. Brauer, D. C. \& Naadimuthu, G. (1992), A Goal Programming Model for aggregate inventory and distribution planning. Mathl. Computational Modelling, 16(3), 81-90.

69. Bravo, M., \& Gonzalez, I. (2009). Applying stochastic goal programming: a case study on water use planning. European Journal of Operational Research 196, 1123-1129

70. Bravo, M., Pla Santamaria, D., \& Garcia-Bernabeu, A. (2010). Portfolio Selection from Multiple Benchmarks: A Goal Programming Approach to an Actual Case. Journal of Multicriteria Decision Analysis 17, 155-166.

71. Büyüközkan, G., \& Berkol, Ç. (2011). Designing a sustainable supply chain using an integrated analytic network process and goal programming approach in quality function deployment. Expert Systems with Applications, 38(11), 13731-13748.

72. Callahan. J. (1973). An Introduction to Financial Planning through Goal Programming. Cost and Management, January-February, 7-12.

73. Canela, M.Á., \& Collazo, E.P. (2007). Portfolio selection with skewness in emerging market industries. Emerging Markets Review, 8, 230-250.

74. Carillo, M., \& Jorge, J. (2006). Multiobjective decision support for the tourist sector, Revista Investigacion Operacional 27, 84-92

75. Chan, F. T., \& Swarnkar, R. (2006). Ant colony optimization approach to a fuzzy goal programming model for a machine tool selection and operation allocation problem in an FMS. Robotics 8 ComputerIntegrated Manufacturing, 22(4), 353-362.

76. Chang, C.T., Chen, H.M. \& Zhuang, Z.Y. (2012a), Revised multi-segment goal programming: Percentage goal programming. Computers $\&$ Industrial Engineering 63, 1235-1242.

77. Chang, C.T., Chen, H.M. \& Zhuang, Z.Y. (2012b), Multi-coefficients goal programming. Computers E Industrial Engineering 62, 616-623.

78. Charles H. Fine Boaz Golany, \& Hussein Naseraldin, (2005). Modeling tradeoffs in three-dimensional concurrent engineering: a goal programming approach. Journal of Operations Management 23(3-4) 389-403.

79. Charnes, A., \& Cooper, W.W. (1961). Management Models and Industrial Applications of Linear Programming. New York: John Wiley \& Sons, Inc.

80. Charnes, A., \& Reinecke W. (1968a), A Goal Programming Model for Media Planning. Management Science, 14 (8), 13423-13430.

81. Charnes, A., Cooper, W., DeVoe, J., Lerner, D., \& Reinecke, W. (1968b), A Goal Programming Model for Media Planning. Management Science, 14, B423.

82. Charnes, A., Cooper, W.W. \& Ferguson, R.O. (1955). Optimal estimation of executive compensation by linear programming. Management Science, 2, 138-151.

83. Charnes, A., Cooper, W.W., Learner, D.B. \& Phillips, F.Y. (1985), Management Science and Marketing Management. Journal of Marketing, 49(2), 93-105.

84. Chen, L. H., \& Tsai, F. C. (2001). Fuzzy goal programming with different importance and priorities. European Journal of Operational Research, 133(3), 548-556.

85. Chen, L. H., \& Weng, M. C. (2006). An evaluation approach to engineering design in QFD processes using fuzzy goal programming models. European Journal of Operational Research, 172(1), 230-248.

86. Chen, L.H., \& Tsai, F.C. (2001). Fuzzy Goal Programming with Different Importance and Priorities. European Journal of Operational Research, 133, 548-556.

87. Chen, V. Y. (1994). A 0-1 goal programming model for scheduling multiple maintenance projects at a copper mine. European Journal of Operational Research, 76(1), 176-191. 
88. Chen, Y. L., Chen, L. H., \& Huang, C. Y. (2009). Fuzzy Goal Programming approach to solve the equipment purchasing problem of an FMC. International Journal of Industrial Engineering: Theory, Applications 8 Practice, 16(4), 270-281.

89. Cherif, M., Chabchoub, H., \& Aouni, B. (2008). Quality control system design through the goal programming model and the satisfaction functions. European Journal of Operational Research, 186(3), 1084-1098

90. Chin-Nung Liao, \& Hsing-Pei Kao, (2011). An integrated fuzzy TOPSIS and MCGP approach to supplier selection in supply chain management, Expert Systems with Applications, 38(9): 10803-10811

91. Chisman, J.A. \& Rippy D. (1979). Optimal operation of a multipurpose reservoir using goal programming. Clemson University Review of Industrial Management and Textile Science 18, 69-82

92. Chunhachinda, P., Dandapani, K., Hamid, S., \& Prakash, A. J. (1997). Portfolio selection and skewness: Evidence from international stock markets. Journal of Banking and Finance 21, 143-167.

93. Colapinto, C., Liuzzi, D., Marsiglio, S. (2014). Sustainability \& intertemporal equity: a multicriteria approach, Mimeo

94. Colson, G., \& De Bruyn, Ch. (1989). An Integrated Multi-Objective Portfolio Management System. Mathematical \& Computer Modeling, 12(10), 1359-1381.

95. Cooper, W.W., Lelas, V., \& Sueyoshi, T. (1997). Goal programming models and their duality relations for use in evaluating security portfolio and regression relations. European Journal of Operational Research, 98, 431-443.

96. Dane, C.W., Meador, N., \& White, J. (1977). Goal programming in land-use planning. Journal of Forestry 75, 325-329

97. Dash, G., \& Kajiji, N. (2005). A nonlinear goal programming model for efficient asset-liability management of property-liability insurers. INFOR, 43(2), 135-156

98. Davis, K.R., \& Taylor III, B.W. (1980). A goal programming model for allocating state promotional effort to regional markets in accordance with tourism potential. Journal of Travel Research 18, 24-30

99. Davies, R.J., Kat, H.M., \& Lu, S. (2009). Fund of hedge funds portfolio selection: A multiple-objective approach. Journal of Derivatives and Hedge Funds, 15(2), 91-115

100. De Kluyver, C. (1979). An Exploration of Various Goal Programming Formulations-with Applications to Advertising Media Scheduling. Journal of the Operational Research Society, 30(2), 167-171.

101. Deb, K. (2001). Nonlinear goal programming using multi-objective genetic algorithms. Journal of the Operational Research Society, 291-302.

102. Delice, E. K., \& Güngör, Z. (2011). A mixed integer goal programming model for discrete values of design requirements in QFD. International journal of production research, 49(10), 2941-2957.

103. Deng, X.T, Li, Z.F., \& Wang S.Y. (2005). A minimax portfolio selection strategy with equilibrium. European Journal of Operational Research, 166, 278-292

104. Dhingra, A. K., Rao, S.S., \& Kumar, V. (1992). Nonlinear Membership Functions in Multiobjective Fuzzy Optimization of Mechanical and Structural Systems. AIAA Journal, 30, 251-260.

105. Diminnie, C.B., \& Kwak, N.K. (1986). A hierarchical goal-programming approach to reverse resource allocation in institutions of higher learning. Journal of the Operational Research Society 37, 59-66

106. Dominiak, C., (1997). An application of interactive multiple goal programming on the Warsaw Stock Exchange. In R.Caballero, F. Ruiz, \& R.E. Steuer.(Eds.), Advances in Multiple Objective and Goal Programming (pp. 66-74). Berlin: Springer Verlag.

107. Dowlatshahi, S. (2001). Product life cycle analysis: a goal programming approach. Journal of the Operational Research Society, 52(11), 1201-1214.

108. Edwards-Jones, G., \& Davies, B., Hussain, S. (2000). Ecological economics: an introduction (Oxford: Blackwell Science) 
109. Elton, E.J. \& Gruber, M. J. (1987). Modern Portfolio Theory and Investment Analysis, (3rd Ed). New York: Wiley.

110. Erdem, A. S., \& Göçen, E. (2012). Development of a decision support system for supplier evaluation and order allocation. Expert Systems with Applications,39(5), 4927-4937.

111. Erol, I., \& Ferrell Jr, W. G. (2009). Integrated approach for reorganizing purchasing: theory and a case analysis on a Turkish company. Computers \& Industrial Engineering, 56 (4), 1192-1204.

112. Ferretti, A.P. (1970). Investment Company Portfolio Management. Irwin inc, (173-182).

113. Freeling, A. N. S. (1980). Fuzzy Sets \& Decision Analysis. IEEE Transactions on Systems, 10, 341-354.

114. Gagnon R.J. \& Sheu C. (1997), A Strategic MIGP Model For Acquiring Advanced Technologies. Computers \& Industrial Engineering, Vol. 32, No1, 145-168.

115. Ge Wang, Samuel H. Huang, \& Dismukes, J.P. (2004), Product-driven supply chain selection using integrated multi-criteria decision-making methodology. International Journal of Production Economics, 91(1):1-15

116. Gen, M., Ida, K., Sasaki, M., \& Lee, J. U. (1989). Algorithms for solving large-scale 0-1 goal programming and its application to reliability optimization problem. Computers $\&$ industrial engineering, 17(1), 525-530.

117. Gen, M., Ida, K. \& Lee, J.-U. (1990), A computational algorithm for solving 0-1 goal programming with GUB structures and its application for optimization problems in system reliability. Electron. Comm. Jpn. Pt. III, 73: 88-96. doi: 10.1002/ecjc.4430731210

118. Gen, M., Ida, K., Tsujimura, Y., \& Kim, C. E. (1993). Large-scale 0-1 fuzzy goal programming and its application to reliability optimization problem. Computers $\&$ Industrial Engineering, 24(4), 539-549.

119. Ghars, L., Altal, S. \& Dhiaf, M.M. (2014), Modeling the Performance in a Just in Time Context Using Goal Programming Approach. Modern Management Science 85 Engineering, 2(1), 68-84.

120. Ghasemi Y., R., Ghomia, S.M.T. \& Torabib, S.A. (2013), A possibilistic multiple objective pricing and lot-sizing model with multiple demand classes. Fuzzy Sets and Systems, 231, 26-44

121. Ghasemy Y., R., Torabi, S. A., \& Ghomi, S. M. T. (2012). Integrated markdown pricing and aggregate production planning in a two echelon supply chain: A hybrid fuzzy multiple objective approach. Applied Mathematical Modelling, 36(12), 6011-6030.

122. Gladish, B., Jones, D., Tamiz, M., \& Terol, B. (2007). An interactive three-stage model for mutual funds portfolio selection. International Journal of Management Science, Omega, 35, 75-88.

123. Goicoechea, A., Stakhiv, E.Z., \& Li, F. (1992). Experimental evaluation of multiple criteria models for application to water resource planning, Journal of the American Water Resources Association 28, 89-102

124. Gökçen, H., \& Agpak, K. (2006). A goal programming approach to simple U-line balancing problem. European Journal of Operational Research, 171(2), 577-585.

125. Goodman, D.A., (1974). A goal programming approach to aggregate planning of production and workforce. Management Science, 20(12), 1569-1575.

126. Gozlu, S., Bayraktar, D., \& Baykas, S. (1999). Improvement of capacity utilization in a subcontracting small scale manufacturing company. Computers 83 Industrial Engineering, 37 31-34.

127. Gupta, M., \& Bhattacharjee, D. (2010). Min Sum Weighted Fuzzy Goal Programming Model in Investment Management Planning: A Case Study. International Research Journal of Finance and Economics, 56 , 76-81.

128. Hallerbach, W.G. \& Spronk, J. (1986). An Interactive Multi-Factor Portfolio Model, Report 8610/F, Centre for research in Business Economics, Erasmus University, Rotterdam.

129. Hannan, E.L. (1981a). On Fuzzy Goal Programming. Decision Sciences, 12, 522-531.

130. Hannan, E.L. (1981b). Some Further Comments on Fuzzy Priorities. Decision Sciences, 12, 539-541. 
131. Han, C., \& Ham, I. (1986). Multiobjective cluster analysis for part family formations. Journal of Manufacturing Systems, 5(4), 223-230.

132. Harrington, T. \& Fisher, W. (1980). Portfolio Modeling in Multiple Criteria Situations under Uncertainty: Comment. Decision Sciences, Winter, 171-177

133. Hassan, N., \& Loon, L.L. (2012). Goal programming with utility function for funding allocation of a university library. Applied Mathematical Sciences 6, 5487-5493

134. Ho, H. P., Chang, C. T., \& Ku, C. Y. (2013). On the location selection problem using analytic hierarchy process and multi-choice goal programming. International Journal of Systems Science, 44(1), 94-108.

135. Hobbs B.F., Chankong, V., Hamadeh, W., \& Stakhiv, E.Z. (1992). Does choice of multicriteria method matter? An experiment in water resources planning Water Resources Research 28, 1767-1780

136. Hoffman, J. J \& Schniederjans, M. J. (1990). An international strategic management/goal programming model for structuring global expansion decisions in the hospitality industry: the case of Eastern Europe. International Journal of Hospitality Management, 9(3), 175-190.

137. Hoffman, J. J., Schneiderjans, M. J. \& Flynn, L. (1996). Test Market City Evaluation: A Goal Programming Approach. Journal of Product and Brand Management, 3, 24-31.

138. Hoshino, T., Yura, K., \& Hitomi, K. (1995). Optimization analysis for recycle-oriented manufacturing systems. International Journal of Production Research, 33(8), 2069-2078.

139. Hwang, C. L., Lee, H. B., Tiliman, F. A., \& Lie, C. H. (1984). Nonlinear integer goal programming applied to optimal system reliability. Reliability, IEEE Transactions on, 33(5), 431-438.

140. Ignizio, J.P. (1976). Goal Programming \& Extensions, Lexington, Mass.: Heath, Lexington Books, Lexington, MA.

141. Ignizio, J.P. (1982). Notes \& Communications of the (Re) Discovery of Fuzzy Goal Programming. Decision Sciences, 13, 331-336.

142. Inuiguchi, M., \& Ramik, J. (2000). Possibilistic linear programming: a brief review of fuzzy mathematical programming and a comparison with stochastic programming in portfolio selection problem. Fuzzy Sets and Systems, 111(1), 3-28.

143. Iranmanesh, H. \& Thomson, V. (2008). Competitive advantage by adjusting design characteristics to satisfy cost targets. International Journal of Production Economics, 115, 64- 71.

144. Jääskeläinen, V. (1969). A goal programming model of aggregate production planning. The Swedish Journal of Economics, 14-29.

145. Jenal, R., Ismail, W.R., Yeun, L.C., \& Oughalime, A. (2011). A cyclical nurse schedule using goal programming ITB Journal of Science 43A, 151-164

146. Jha, P.C., Aggarwal, R. \& Gupta, A. (2011). Optimal media planning for multi-products in segmented market. Applied Mathematics and Computation, 217, 6802-6818.

147. Jha, P.C., \& Aggarwal, R. (2012). Optimal advertising media allocation under fuzzy environment for a multi-product segmented market. Turkish Journal of Fuzzy Systems, 3(1), 45-64.

148. Ji, X., Zhu, S., Wang, S., \& Zhang, S. (2005). A stochastic linear goal programming approach to multistage portfolio management based on scenario generation via linear programming. IIE Transactions, 37, 957-969.

149. Jobst, N., Horniman, M., Lucas, C., \& Mitra, G. (2001). Computational aspects of alternative portfolio selection models in the presence of discrete asset choice constraints. Quantitative Finance, 1(5), 1-13.

150. Jones, D. \& Tamiz, M. (2010) Case Study: Application of Goal Programming in Portfolio Selection. In D. Jones \& M. Tamiz, Practical Goal Programming, International Series in Operations Research \& Management Science, Springer Science+Business Media.

151. Jones, D. \& Tamiz, M. (1995). Expanding the flexibility of goal programming via preference modelling techniques. Omega, 23(1), 41-48. 
152. Jones, D. F., \& Tamiz, M. (2002). Goal programming in the period 1990-2000. In Multiple Criteria Optimization: State of the art annotated bibliographic surveys (pp. 129-170). Springer US.

153. Jones, D.F., Collins, A. \& Han, C. (2007). A classification model based on goal programming with nonstandard preference functions with application to the prediction of cinema-going behavior. European Journal of Operational Research, 177, 515-524.

154. Josefa Mula, David Peidro, Manuel Díaz-Madroñero, \& Eduardo Vicens, (2010). Mathematical programming models for supply chain production and transport planning. European Journal of Operational Research, 204(3), 377-390.

155. Junyan Wang, Ruiqing Zhao, \& Wansheng Tang, (2008). Fuzzy Programming Models for Vendor Selection Problem in a Supply Chain. Tsinghua Science 85 Technology, 13(1):106-111

156. Kalpić, D., Mornar, V., \& Baranović, M. (1995). Case study based on a multi-period multi-criteria production planning model. European Journal of Operational Research, 87(3), 658-669.

157. Kao, C., \& Brodie, J. (1979). Goal programming for reconciling economics, even flow, and regulation objectives in forest harvest scheduling. Canadian Journal of Forest Research 9, 525-531

158. Kar, A. K. (2014). Revisiting the supplier selection problem: An integrated approach for group decision support. Expert systems with applications, 41(6), 2762-2771.

159. Karpak, B., Kumcu, E., \& Kasuganti, R. (1999). An application of visual interactive goal programming: a case in vendor selection decisions. Journal of Multi-Criteria Decision Analysis, 8(2), 93-105.

160. Karsak, E. E., \& Kuzgunkaya, O. (2002). A fuzzy multiple objective programming approach for the selection of a flexible manufacturing system. International Journal of Production Economics, 79(2), 101-111.

161. Karsak, E. E., Sozer, S., \& Alptekin, S. E. (2003). Product planning in quality function deployment using a combined analytic network process and goal programming approach. Computers $\&$ Industrial Engineering, 44(1), 171-190.

162. Karsak, E. E., Sozer, S., \& Alptekin, S. E. (2003). Product planning in quality function deployment using a combined analytic network process and goal programming approach. Computers $\&$ Industrial Engineering, 44(1), 171-190.

163. Kendall, K. E., \& Schniederjans, M. J. (1985). Multi-product production planning: A goal programming approach. European Journal of Operational Research, 20(1), 83-91.

164. Keown, A. J. \& Taylor III B. W. (1978), Integer goal programming model for the implementation of multiple corporate objectives. Journal of Business Research, 6( 3), 221-235.

165. Keown, A. J. \& Duncan, C. P. (1979). Integer Goal Programming in Advertising Media Selection. Decision Sciences, 10: 577-592.

166. Keown, A.J., \& Martin, J.D. (1976). An integer GP model for capital budgeting in hospitals Financial Management 5, 28-35

167. Khalili-Damghani, K. \& Sadi-Nezhad, S. (2013). A decision support system for fuzzy multi-objective multi-period sustainable project selection. Computers $\mathscr{E}$ Industrial Engineering, 64, 1045-1060.

168. Kocadağll, O. \& Keskin, R. (2014). A Novel Portfolio Selection Model With Preemptive Fuzzy Goal Programming, Conference: Make Learn 2014: Human Capital without Borders: Knowledge and Learning for Quality of Life, At Portoroz, Slovenia

169. Kongar, E., \& Gupta, S. M. (2001). Goal programming approach to the remanufacturing supply-chain model. In Intelligent Systems and Smart Manufacturing, 167-178, International Society for Optics \& Photonics.

170. Konno, H., \& Yamazaki, H. (1991). Mean-absolute deviation portfolio optimization and its applications to Tokyo stock market. Management Science, 37(5), 19-31. 
171. Kosmidou, K., \& Zopounidis, C. (2004). Combining goal programming model with simulation analysis for bank asset liability management. INFOR, 42(3), 175-187.

172. Kumar Tayi, G. (1985). A polynomial goal programming approach to a class of quality control problems. Journal of Operations Management, 5(2), 237-246.

173. Kumar, P., Singh, N., \& Tewari, N. K. (1987). A nonlinear goal programming model for the loading problem in a flexible manufacturing system. Engineering Optimization+, A35, 12(4), 315-323.

174. Kumar, P.C., \& Philippatos, G.C. (1979). Conflict Resolution in Investment Decisions: Implementation of Goal Programming Methodology for Dual-Purpose Funds. Decision Sciences. October, 562-576.

175. Kumar, P.C., Philippatos, G.C., \& Ezell, J.R. (1978). Goal programming and the selection of portfolios by dual purpose funds. The Journal of Finance, 33(1), March, 303-310.

176. Kvanli, A.H. (1980). Financial planning using goal programming. Omega, 8(2), 207-218.

177. Kwak, N.K., \& Diminnie, C.B. (1987). A goal programming model for allocating operating budgets of academic units Socio-economic Planning Science 21, 333-339

178. Kwak, N.K., Lee, C. W. \&, Kim, J. H. (2005), An MCDM model for media selection in the dual consumer/industrial market, European Journal of Operational Research 166 255-265

179. Kwak, N.K., Schniederjans, M. J. \& Warkentin, K. S. (1991), An application of linear goal programming to the marketing distribution decision European Journal of Operational Research, 52(3), 17, 334-344

180. La Torre, D., \& Maggis, M. (2012). A Goal Programming Model for Optimal Portfolio Diversi?cation, Information Systems and Operations Research, 50(3), 117-126.

181. Lai, K. K., Yu, L., \& Wang, S. Y. (2006). Mean-variance-skewness- kurtosis-based portfolio optimization. In Proceedings of the First International Multi-Symposiums on Computer and Computational Sciences, 2, 292-297.

182. Lai, T. Y. (1991). Portfolio selection with skewness: A multi-objective approach. Review of Quantitative Finance and Accounting, 1(3), 293-305.

183. Lee S.M. \& Shim, J.P. (1986). Interactive Goal Programming on the Microcomputer to Establish Priorities for Small Business. Journal of the Operational Research Society, Vol. 37, No. 6, pp. 571577.

184. Lee, A. H., Kang, H. Y., \& Chang, C. T. (2009). Fuzzy multiple goal programming applied to TFT-LCD supplier selection by downstream manufacturers. Expert Systems with Applications, 36(3), 6318-6325.

185. Lee, C.W. \& Kwak, N.K. (1999). Information resource planning using AHP-based goal programming model. Journal of Operational Research Society, 51, 1-8.

186. Lee, S. M. (1972). Goal Programming for Decision Analysis, Philadelphia: Auerbach.

187. Lee, S. M. \& Shim, J.P. (1986). Interactive Goal Programming on the Microcomputer to Establish Priorities for Small Business. J. Oper. Res. Soc. Vol. 37, No. 6, pp. 571-577.

188. Lee, S. M., \& Chesser, D. L. (1980). Goal Programming for Portfolio Selection. The Journal of Portfolio Management, Spring, 22-26.

189. Lee, S. M., \& Jung, H. J. (1989). A multi-objective production planning model in a flexible manufacturing environment. International Journal of Production Research, 27(11), 1981-1992.

190. Lee, S. M., \& Lerro, A. J. (1973). Optimizing the portfolio selection for mutual funds. Journal of Finance, 28(5), 1087-1101.

191. Lee, S. M., Clayton, E. R., \& Taylor III, B. W. (1978). A goal programming approach to multi-period production line scheduling. Computers $\&$ Operations Research, 5(3), 205-211. 
192. Lee, S. M., Justis, R. \& Franz, L. (1979) Goal programming for decision making in closely held businesses. Am. J. Small Bus. 3, No. 4, 31-41.

193. Lee, S.M. \& Nicely, R.E. (1974). Goal Programming for Marketing Decisions: A Case Study. Journal of Marketing, 38, 24-32.

194. Lee, S.M., \& Sevebeck, W.R. (1971). An aggregative model for municipal economic planning. Policy Sciences, 2(2), 99-115.

195. Lee, S.M., 1972. Goal Programming for Decision Analysis. Auerbach Publishers, Philadelphia: Pennsylvania.

196. Lee, S.M., \& Clayton, E.R. (1972). A goal programming model for academic resource allocation. Management Science 18, B395-B408

197. Leong, G. K., Oliff, M. D., \& Markland, R. E. (1989). Improved hierarchical production planning. Journal of Operations Management, 8(2), 90-114.

198. Leung, M.T., Daouk, H., \& Chen, A. (2001). Using investment portfolio return to combine forecasts: A multiobjective approach. European Journal of Operational Research, 134, 84-102.

199. Leung, S. C., \& Chan, S. S. (2009). A goal programming model for aggregate production planning with resource utilization constraint. Computers \& Industrial Engineering, 56 (3), 1053-1064.

200. Leung, S. C., \& Ng, W. L. (2007). A goal programming model for production planning of perishable products with postponement. Computers \& Industrial Engineering, 53(3), 531-541.

201. Leung, S. C., Wu, Y., \& Lai, K. K. (2003). Multi-site aggregate production planning with multiple objectives: a goal programming approach. Production Planning 86 Control, 14 (5), 425-436.

202. Levary, R.R., \& Avery, M.L. (1984). On practical application of weighting equities in a portfolio via goal programming. Operation Research, 21, 246-261.

203. Levy, H., \& Sarnat, M. (1972). Investment performance in an Imperfect Securities Market and the Case for Mutual Funds. Financial Analysts Journal, 77-81.

204. Li, D. F., \& Wan, S. P. (2014). A fuzzy inhomogenous multiattribute group decision making approach to solve outsourcing provider selection problems. Knowledge-Based Systems, 67, 71-89.

205. Li, G. (2012). Fuzzy goal programming - A parametric approach. Information Sciences, 195, 287-295.

206. Li, J., \& Xu, J. (2007). A class of possibilistic portfolio selection model with interval coefficients and its application. Journal Fuzzy Optimization and Decision Making archive, 6(2), 123-137.

207. Li, L., Fonseca, D. J., \& Chen, D. S. (2006). Earliness-tardiness production planning for just-intime manufacturing: A unifying approach by goal programming. European Journal of Operational Research, $175(1), 508-515$.

208. Liang, T. F. (2006). Distribution planning decisions using interactive fuzzy multi-objective linear programming. Fuzzy Sets and Systems, 157(10), 1303-1316.

209. Liang, T. F. (2007). Applying fuzzy goal programming to production/transportation planning decisions in a supply chain. International Journal of Systems Science, 38(4), 293-304.

210. Liang-Hsuan Chen \& Ming-Chu Weng. (2006). An evaluation approach to engineering design in QFD processes using fuzzy goal programming models, European Journal of Operational Research, 172(1): 230-248

211. Liao, C. N. (2011). Fuzzy analytical hierarchy process \& multi-segment goal programming applied to new product segmented underprice strategy. Computers 83 Industrial Engineering, 61 (3), 831-841.

212. Liao, C. N., \& Kao, H. P. (2010). Supplier selection model using Taguchi loss function, analytical hierarchy process and multi-choice goal programming. Computers $\mathcal{E}$ Industrial Engineering, 58(4), 571-577.

213. Liao, C.N. (2009) Formulating the multi-segment goal programming. Computers $\&$ Industrial Engineering, 56, 138-141. 
214. Liao, C.N. \& Chih, I-L. (2014). Knowledge management system selection by multi-choice goal programming. Human Systems Management, 33 (1-2), 19-25.

215. Limanei, S.M., Kouhi, M.S., \& Sharaji, T.R. (2014). Goal programming approach for sustainable forest management (case study in Iranian Caspian forests). Journal of Forestry Research 25, 429-435

216. Lin, H. W., Nagalingam, S. V., \& Lin, G. C. (2009). An interactive meta-goal programming-based decision analysis methodology to support collaborative manufacturing. Robotics and Computer-Integrated Manufacturing, 25(1), 135-154.

217. Lin, T.W., \& O’Leary, D.E. (1993). Goal Programming Application in Financial Management. In Lawrence, K.D., Guerard, J.B., \& Reeves, G.R., Advances in Mathematical Programming and Financial Planning, 3, JAI Press Inc.: 211-229.

218. Lin, W. T. (1980). A survey of goal programming applications. Omega, 8(1), 115-117

219. Linares P, \& Romero C. (2000). A multiple criteria decision making approach for electricity planning in Spain: economic versus environmental objectives Journal of Operational Research Society 51, 736-743

220. Linares, P., \& Romero, C. (2002). Aggregation of preferences in an environmental economics context: A goal-programming approach. Omega 30, 89-95

221. Liu, E., Hsiao, S.-W., \& Hsiao, S.-W. (2014). A decision support system for product family design. Information Sciences, 281, 113-127.

222. Lotfi, M.M. \& Torabi, S.A. (2011). A fuzzy goal programming approach for mid-term assortment planning in supermarkets. European Journal of Operational Research, 213, 430-441.

223. Lucey, B., Tully, E. \& Poti, V. (2004), International Portfolio Formation, Skewness \& the Role of Gold. IIIS Discussion Paper N. 30.

224. Mahapatra, N., \& Maiti, M. (2005). Decision process for multiobjective, multi-item productioninventory system via interactive fuzzy satisficing technique. Computers $\&$ Mathematics with Applications, 49(5), 805-821.

225. Manoj Kumar, Prem Vrat, \& Shankar, R. (2004). A fuzzy goal programming approach for vendor selection problem in a supply chain. Computers $\mathcal{E}$ Industrial Engineering, 46(1): 69-85

226. Manoj Kumar, Prem Vrat, \& Shankar, R. (2006). A fuzzy programming approach for vendor selection problem in a supply chain. International Journal of Production Economics, 101(2):273-285

227. Mansour, N., Rebaï, A., \& Aouni, B. (2007). Portfolio Selection Through the Imprecise Goal Programming Model: Integration of Manager's Preferences. Journal of Industrial Engineering International, $3(5), 1-8$.

228. Mariappan, V., Babu, A. S., Rajasekaran, S., \& Ilayaraja, K. (2011). Collaborative optimal preventive maintenance schedule using goal programming. International Journal of Advanced Operations Management, 3(2), 153-174.

229. Markland, R. E., \& Vickery, S. K. (1986). The efficient computer implementation of a large-scale integer goal programming model. European Journal of Operational Research, 26(3), 341-354.

230. Markowitz, H. M. (1959). Portfolio Selection: Efficient Diversification of Investments, New York: Wiley.

231. Markowitz, H. M. (1952). Portfolio Selection. The Journal of Finance, 7, 77-91.

232. Martel, J. M., \& Aouni, B. (1990). Incorporating the decision maker's preferences in the Goal Programming model. Journal of Operational Research Society, 41, 1121-1132.

233. Martel, J. M., \& Aouni, B. (1998). Diverse imprecise goal programming model formulations. Journal of Global Optimization, 12(2), 127-138.

234. Marten, G.G. \& Sancholuz, L.A. (1982) Ecological land-use planning and carrying capacity evaluation in the Jalapa region (Veracruz, Mexico), Agro-Ecosystems 8, 83-124 
235. Mazaher Ghorbani, S. Mohammad Arabzad, \& Reza Tavakkoli-Moghaddam, (2014). A multi-objective fuzzy goal programming model for reverse supply chain design. Int. J. of Operational Research, 19(2): $141-153$

236. McGrew, J.C. (1975). Goal programming and complex problem-solving in geography, Papers in geography 12, Department of Geography, Pennsylvania State University

237. Mendoza, G.A., \& Martins, H. (2006). Multi-criteria decision analysis in natural resource management: a critical review of methods and new modelling paradigms, Forest Ecology and Management 230 1-22

238. Min, H. \& Melachrinoudis, E. (1996). Dynamic location and entry mode selection of multinational manufacturing facilities under uncertainty: A chance-constrained goal programming approach. International Transactions in Operational Research, 3(1), 65-76.

239. Min, H., \& Storbeck, J. (1991). On the origin and persistence of misconceptions in goal programming. Journal of the Operational Research Society, 301-312.

240. Mirkarimi, S.H., Joolaie, R., Eshraghi, F., \& Abadi, S.B. (2013). Application of fuzzy goal programming in cropping pattern management of selected crops in Mazandaran province (case study Amol township), International Journal of Agriculture \&5 Crop Sciences 6, 1062-1067

241. Mishra, S., Prakash, Tiwari, M. K., \& Lashkari, R. S. (2006). A fuzzy goal-programming model of machine-tool selection and operation allocation problem in FMS: a quick converging simulated annealing-based approach. International Journal of Production Research, 44(1), 43-76

242. Mitra, A. \& Patankar, J. G. (1990). A multi-objective model for warranty estimation. European Journal of Operational Research, 45 (2-3), 347-355.

243. Muhlemann, A., \& Lockett, A. (1980). Portfolio Modeling in Multiple Criteria Situations under Uncertainty: Rejoinder. Decision Sciences. Winter, 178-180.

244. Muhlemann, A.P., Lockett, A.G., \& Gear, A.E. (1978). Portfolio modelling in multiple-criteria situations under uncertainty. Decision Sciences, 9, 612-626.

245. Munoz M., L., \& Ramos, A. (1999). Goal programming approach to maintenance scheduling of generating units in large scale power systems. Power Systems, IEEE Transactions on, 14(3), 10211028 .

246. Munro, M., \& Aouni, B. (2009). Group decision-making through the goal programming model : stateof-the-art and a new typology, Administrative Sciences Association of Canada. Management Science 30

247. Narasimhan, R. (1980). Goal Programming in a Fuzzy Environment. Decision Sciences, 11, 325-336.

248. Nixon, P.K. Dey, P.A. Davies, S. Sagi, \& R.F. Berry, (2014). Supply chain optimisation of pyrolysis plant deployment using goal programming. Energy, 68:262-271.

249. O'Leary, J.H. \& O'Leary, D.E. (1987). A multiple goal approach to the choice of pension fund management. In K.D. Lawrence, J.B. Guerard \& G.R. Reeves (Eds.), Advances in Mathematical Programming E Financial Planning, (Vol. 1, 187-195)., Greenwich, CT: JAI Press.

250. Özcan, U., \& Toklu, B. (2009). Multiple-criteria decision-making in two-sided assembly line balancing: a goal programming and a fuzzy goal programming models. Computers 83 Operations Research, 36(6), 1955-1965.

251. Ozkarahan, I., \& Bailey, J.E. (1988). Goal programming model subsystem of a flexible nurse scheduling support system, IIE Transactions 20, 306-316

252. Paksoy, C. \& Chang, T.(2010) Revised multi-choice goal programming for multi-period, multi-stage inventory controlled supply chain model with popup stores in Guerilla marketing. Appl. Math. Model. 34 (2010) 3586-3598.

253. Paras Deshpande, Deepak Shukla, \& Tiwari, M.K. (2011). Fuzzy goal programming for inventory management: A bacterial foraging approach, European Journal of Operational Research, 212(2): 325336 
254. Pati, R. K., Vrat, P., \& Kumar, P. (2008). A goal programming model for paper recycling system. Omega, 36(3), 405-417.

255. Pendaraki, K., Doumpos, M., \& Zopounidis, C. (2004). Towards a Goal Programming Methodology for Constructing Equity Mutual Fund Portfolios. Journal of Asset Management, 4(6), 415-428.

256. Pendaraki, K., Zopounidis, C., \& Doumpos, M. (2005). On the Construction of Mutual Fund Portfolios: A Multicriteria Methodology and An Application to the Greek Market of Equity Mutual Fund. European Journal of Operational Research, 163(2), 462-481.

257. Perçin, S. (2006). An application of the integrated AHP-PGP model in supplier selection. Measuring Business Excellence, 10(4), 34-49.

258. Perez G., B., Jones D.F., Tamiz M., \& Bilbao T., A. (2007) An interactive three stage model for mutual fund portfolio selection, Omega-International Journal of Management Science, 35, 75-88.

259. Powell, J.G., \& Premachandra, I. M. (1998). Accommodating diverse institutional investment objectives and constraints using non-linear goal programming. European Journal of Operational Research, 105, 173-187.

260. Prakash, A.J., Chang, C., \& Pactwa, T.E. (2003). Selecting a portfolio with skewness: Recent evidence from US, European, and Latin American equity markets. Journal of Banking and Finance, 27, 13751390.

261. Rai, R., Kameshwaran, S., \& Tiwari, M. K. (2002). Machine-tool selection and operation allocation in FMS: solving a fuzzy goal-programming model using a genetic algorithm. International Journal of Production Research, 40(3), 641-665.

262. Ramadan H.M. (1997). The relationship between goal programming and fuzzy programming. Fuzzy Sets and Systems, 89(2) 215-222

263. Ramanathan, R. (2012), A mathematical programming model for estimating the importance levels of performance criteria and an application in e-commerce. Expert Systems with Applications, 39, 2067-2072.

264. Rao, S. S. (1987). Multi-Objective Optimization of Fuzzy Structural Systems. International Journal for Numerical Methods in Engineering, 24, 1157-1171.

265. Reddy, P. B. S., Nishina, K. \& Babu, A. S. (1997). Unification of robust design and goal programming for multiresponse optimization-A case study. Qual. Reliab. Engg. Int., 13: 371-383.

266. Reyes, P. M., \& Frazier, G. V. (2007). Goal programming model for grocery shelf space allocation. European Journal of Operational Research, 181, 634-644.

267. Rifai, A. \& Hanna, N. (1975). Planning the Media Mix through Goal Programming, The American Economist, 19, 2: 21-26.

268. Rifai, A.K., \& Pecenka, J.O. (1989). An application of goal programming in healthcare planning, International Journal of Production Management 10, 28-37

269. Romero, C. (1986). A survey of generalized goal programming 1970-1982. European Journal of Operational Research, 25(2), 183-191.

270. Romero, C. (1991). Handbook of Critical Issues in Goal Programming. Oxford: Pergamon Press.

271. Romero, C., \& Rehman, T. (1987). Natural resource management and the use of multiple criteria decision making techniques: a review European Review of Agricultural Economics 14, 61-89

272. Rostamy, A., Azar, A., \& Hosseini, S. (2003). A mixed integer goal programming (MIGP) model for multi-period complex corporate financing problems. Finance India, 17(2), 495-509.

273. Saber, H. M., \& Ravindran, A. (1993). Nonlinear goal programming theory and practice: A survey. Computers $\&$ Operations Research, 20(3), 275-291.

274. Sadeghi, M., Hajiagha, S. H. R., \& Hashemi, S. S. (2013). A fuzzy grey goal programming approach for aggregate production planning. The International Journal of Advanced Manufacturing Technology, 64(9-12), 1715-1727. 
275. Sandiford, F. (1986). An analysis of multiobjective decision-making for the Scottish inshore fishery Journal of Agricultural Economics 37, 207-219

276. Sardana, G. D., \& Vrat, P. (1987). Productivity measurement in a large organization with multiperformance objectives: A case study. Engineering Management International, 4 (2), 105-125.

277. Satoglu, S. I., \& Suresh, N. C. (2009). A goal-programming approach for design of hybrid cellular manufacturing systems in dual resource constrained environments. Computers $\&$ Industrial Engineering, 56(2), 560-575.

278. Schinnar, A.P. (1976). A multidimensional accounting model for demographic and economic planning interactions. Environment and Planning A 8, 455-475

279. Schniederjans, M. J. (1995). Goal programming: methodology and applications. Boston, MA: Kluwer Academic Publishers.

280. Schniederjans, M. J.\& Hoffman J. J. (1992), Multinational acquisition analysis: A zero-one goal programming model. European Journal of Operational Research, 62(2), 175-185.

281. Schniederjans, M. J., \& Karuppan, C. M. (1995). Designing a quality control system in a service organization: A goal programming case study. European Journal of Operational Research, 81(2), 249258.

282. Schniederjans, M. J., Kwak, N. K., \& Helmer, M. C. (1982). An application of goal programming to resolve a site location problem. Interfaces, 12(3), 65-72.

283. Schniederjans, M.J. \& Garvin, T., 1997. Using the analytic hierarchy process and multi-objective programming for the selection of cost drivers in activity-based costing. European Journal of Operational Research 100 (1), 72-80.

284. Schroeder, R.G. (1974). Resource planning in university management by goal programming Operations Research 22, 700-710

285. Seely, R.L., Iglarsh, H.J.,\& Edgell, D.L. (1980). Goal programming. Planning process of tourism organizations. Annals of Tourism Research 7, 353-365

286. Selim, H., \& Irem Ozkarahan, (2008a). A supply chain distribution network design model: An interactive fuzzy goal programming-based solution approach. Int J Adv Manuf Technol, 36:401-418.

287. Selim, H., Ceyhun Araz, \& Irem Ozkarahan, (2008b). Collaborative production-distribution planning in supply chain: A fuzzy goal programming approach. Transportation Research Part E: Logistics \& Transportation Review, 44(3): 396-419.

288. Sen, N., \& Nandi, M. (2012). Goal programming approach to rubber plantation planning in Tripura. Applied Mathematical Sciences 6, 6171-6179

289. Sengupta, S. (1981). Goal programming approach to a type of quality control problem. Journal of the Operational Research Society, 207-211.

290. Shafer, S. M., \& Rogers, D. F. (1991). A goal programming approach to the cell formation problem. Journal of Operations Management, 10(1), 28-43.

291. Shanker, R., \& Vrat, P. (1999). Some design issues in cellular manufacturing using the fuzzy programming approach. International Journal of Production Research, 37(11), 2545-2563.

292. Sharda. R., \& Musser, T. (1986). Financial Futures Hedging via Goal Programming. Management Science, 933-947.

293. Sharma, D.K., Jana, R.K., \& Gaur, A. (2007). Fuzzy goal programming for agricultural land allocation problems Yugoslav Journal of Operations Research 17, 31-42

294. Sharma, H., \& Sharma, D. (2006). A multi-objective decision-making approach for mutual fund portfolio. Journal of Business \& Economics Research, 4(6), 13-23.

295. Sharma, H., Ghosh, D., \& Sharma, D. (2007). Credit union portfolio management: an application of goal interval programming. Academy of Banking Studies, 6(1), 39-60. 
296. Sharma, H., Sharma, D., \& Jana, R.K. (2009). Credit Union Portfolio Management - An Additive Fuzzy Goal Programming Approach. International Research Journal of Finance and Economics, 30, 19-28.

297. Sharma, J.K., Sharma, D.K., \& Adeyeye, J.O. (1995). Optimal portfolio selection: A goal programming approach. Indian Journal of Finance and Research 7 (2), 67-76.

298. Sharma, S., \& Balan, S. (2013). An integrative supplier selection model using Taguchi loss function, TOPSIS and multi criteria goal programming. Journal of Intelligent Manufacturing, 24(6), 1123-1130.

299. Sharpe, W.F. (1967). A Linear Programming Algorithm for Mutual Funds Portfolio Selection. Management Science, 13(3), 499-510.

300. Sheikhalishahi, M., \& Torabi, S. A. (2014). Maintenance supplier selection considering life cycle costs and risks: a fuzzy goal programming approach. International Journal of Production Research, (aheadof-print), 1-16.

301. Songsong Liu, \& Papageorgiou, L.G. (2013). Multiobjective optimization of production, distribution and capacity planning of global supply chains in the process industry. Omega, 41(2): 369-382

302. Spronk , J. (1980). Interactive Multiple Goal Programming for Capital Budgeting and Financial Planning. Delft: Delftse Uitgevers Maatschappij.

303. Spronk \& Van Der Wijst (1987). A Multi-Factor framework for firm evaluation, pp 317-330. Retrieved online: http://repub.eur.nl/res/pub/6015/18120.pdf

304. Spronk, J. (1981). Interactive Multiple Goal Programming: Applications to Financial Planning. Boston: Martinus Nijhoff.

305. Steiguer, J.E., Liberti, L., Schuler, A., \& Hansen, B. (2003). Multi-criteria decision models for forestry and natural resources management: an annotated bibliography, General Technical Report NE-307, U.S.D.A. Forest Service, Northeastern Research Station

306. Stern, H.I. (1974). A goal-programming approach to planning for population balance in a multiregional system, Environment and Planning A 6, 431-437

307. Steuer, R.E., \& Na, P. (2003). Multiple criteria decision making combined with finance: A categorized bibliographic study. European Journal of Operational Research, 150, 496-515.

308. Stone, B. K.. \& Reback. R. (1975). Constructing a Model for Managing Portfolio Revisions. Journal of Bank Research. Spring, 48-60.

309. Stoyan, S.J., \& Kwon, R.H. (2011). A Stochastic-Goal Mixed-Integer Programming approach for integrated stock and bond portfolio optimization. Journal Computers and Industrial Engineering, 61 (4), 1285-1295.

310. Sun, Q., \& Yan, Y. (2003). Skewness persistence with optimal portfolio selection. Journal of Banking E Finance, 27, 1111-1121.

311. Swart, W.W., Var, T., \& Gearing, C.E. (1978). Operations research applications to tourism. Annals of Tourism Research 5, 414-428

312. Taghizadeh, K., Bagherpour, M., \& Mahdavi, I. (2011). An interactive fuzzy goal programming approach for multi-period multi-product production planning problem. Fuzzy Information and Engineering, 3(4), 393-410.

313. Tamiz M., Azmi R.A. \& Jones D. F. (2013). On selecting portfolio of international mutual funds using goal programming with extended factors. European Journal of Operational Research 226, 560-576.

314. Tamiz, M., \& Jones, D. (1998). Goal programming: recent developments in theory and practice. International Journal of Management and Systems, 14, 1-16.

315. Tamiz, M., Hasham, R., Fargher, K., \& Jones, D. (1997). A comparison between goal programming and regression analysis for portfolio selection. Lecture notes in Economics and Mathematical Systems, Springer, 448, 421-432. 
316. Tamiz, M., Hasham, R., Jones, D.F., Hesni, B., \& Fargher, E.K. (1996). A two staged goal programming model for portfolio selection. In M. Tamiz, (Ed.), Lecture Notes in Economics 83 Mathematical Systems 432 (286-299). Berlin: Springer.

317. Tamiz, M., Jones, D., \& El-Darzi, E. (1995). A review of Goal Programming and its applications. Annals of Operations Research, 58(1), 39-53

318. Tamiz, M., Jones, D., \& Romero, C. (1998). Goal programming for decision making: An overview of the current state-of-the-art. European Journal of Operational Research, 111(3), 569-581.

319. Taplin, J.H.E., Qiu, M., \& Zhang, Z. (1995a). Allocation of public road funding by goal programming on multiple criteria Australian Journal of Public Administration 54, 58-64

320. Taplin, J.H.E., Qiu, M., \& Zhang, Z. (1995b). Policy-sensitive selection and phasing of road investments with a goal program Transportation Policy 2, 251-256

321. Tayi, G.K. \& Leonard, P.A. (1988). Bank Balance-Sheet Management: An Alternative Multi-Objective Model. The Journal of the Operational Research Society, 39(4), 401-410.

322. Taylor III, B. W., Moore, L. J., \& Clayton, E. R. (1982). R\&D project selection and manpower allocation with integer nonlinear goal programming. Management science, 28(10), 1149-1158.

323. Taylor III, B.W. \& Anderson, Paul F. (1979). Goal programming approach to marketing/ production planning. Industrial Marketing Management, 8(2), 136-144.

324. Taylor III, B.W., \& Keown, A.J. (1978). Planning urban recreational facilities with integer goal programming, Journal of the Operational Research Society 29, 751-758

325. Tektas, A., Ozkan, G., E., \& Gunay, G. (2005). Asset and liability management in financial crisis. Journal of Risk Finance 6(2), 135-149.

326. Tien-Fu Liang, (2008). Fuzzy multi-objective production/distribution planning decisions with multiproduct and multi-time period in a supply chain, Computers \& Industrial Engineering, 55(3): 676-694

327. Tingley, K.M. \& Liebman, J.S. (1984). A goal programming example in public health resource allocation Management Science 30, 279-289

328. Topaloglu, S., \& Ozkarehan, I. (2004). An implicit goal programming model for the tour scheduling problem considering the employee work preferences. Annals of Operations Research 128, 135-158

329. Torabi , S. A., \& Hassini, E. (2009). Multi-site production planning integrating procurement and distribution plans in multi-echelon supply chains: an interactive fuzzy goal programming approach. International Journal of Production Research, 47(19), 5475-5499.

330. Torabi, S. A., \& Moghaddam, M. (2012). Multi-site integrated production-distribution planning with trans-shipment: a fuzzy goal programming approach. International Journal of Production Research, 50(6), 1726-1748.

331. Trenado, M., Romero, M., Cuadrado, M.L. \& Romero, C. (2014). Corporate social responsibility in portfolio selection: A "goal games" against nature approach. Computers $\&$ Industrial Engineering 75, 260-265.

332. Tsai, K.M., You, S.Y., Lin, Y.H. \& Tsai, C.H. (2008). A fuzzy goal programming approach with priority for channel allocation problem in steel industry. Expert Systems with Applications, 34, 18701876.

333. Tsai, W.H. \& Chou, W.C. (2009). Selecting management systems for sustainable development in SMEs: A novel hybrid model based on DEMATEL, ANP, \& ZOGP. Expert Systems with Applications, $36,1444-1458$.

334. Tsai, S.J.H. (2009). A fuzzy goal programming approach for green supply chain optimization under activity-based costing and performance evaluation with a value-chain structure, International Journal of Production Research, 47(18): 4991:5017. 
335. Tsai, W.H. \& Kuo, H.C. (2011). Entrepreneurship policy evaluation and decision analysis for SMEs. Expert Systems with Applications 38 8343-8351.

336. Tsai, W.-H., Leu, J.-D., Liu, J.-Y., Lin, S.-J. \& Shaw, M. J. (2010) A MCDM approach for sourcing strategy mix decision in IT projects. Expert Systems with Applications, 37, 3870-3886.

337. Tyagi, S.K., Yang, K., Tyagi, A. \& Dwivedi, S. N. (2011) Development of a fuzzy goal programming model for optimization of lead time and cost in an overlapped product development project using a Gaussian Adaptive Particle Swarm Optimization-based approach. Engineering Applications of Artificial Intelligence, 24, 866-879.

338. Verma, M.K., \& Shrivastava, R.K. (2000). Optimal operation of multiple reservoir systems by weighted goal programming, Journal of Indian Water Resources Society 20, 27-34

339. Verma, M.K., \& Shrivastava, R.K. (2001). Min-max goal programming: an application to Mahanadi reservoir project complex Canadian Journal of Civil Engineering 28, 684-690

340. Verma, M.K., Shrivastava, R.K., \& Tripathi, R.K. (2010). Evaluation of min-max, weighted and preemptive goal programming techniques with reference to Mahanadi reservoir project complex Water Resources Management 24, 299-319

341. Walter, B., Kerstens, K., \& Van de Woestyne, I. (2013). Portfolio selection with skewness: A comparison of methods and a generalized one fund result. European Journal of Operational Research 230, 412-421.

342. Wang, B., Zhang, M.L, \& Jia, W. (2008). Estimation of optimal advertising expenditure based on customer value. 2008 International Conference on Management Science, 641-648.

343. Wang, S. \& Zhu, S. (2002). On fuzzy portfolio selection problems. Fuzzy Optimization and Decision Making, 1(4), 361-377

344. Wang, Y.M., \& Chin, K.S. (2008). A linear goal programming priority method for fuzzy analytic hierarchy process and its applications in new product screening. International Journal of Approximate Reasoning 49, 451-465.

345. Watada J. (1997). Fuzzy portfolio selection \& its application to decision making. Tatra Mountains Mathematical Publications, 13, 219-248.

346. William Ho, Xiaowei Xu, \& Dey, P.K. (2010). Multi-criteria decision making approaches for supplier evaluation and selection: A literature review. European Journal of Operational Research, 202(1): 16-24

347. Xu, Q., Jiang, C. \& King, P. (2007). Dynamic Portfolio Selection with Higher Moments Risk Based on Polynomial Goal Programming. Proceedings of the International Conference on Management Science 83 Engineering, 2152-2157.

348. Yura, K., Ohashi, K., Nakajima, M., Yoshimura, M. Ota, M \& Hitomia, K. (1994), Strategic planning for CIM to enhance the competitive ability. Computers $\& 3$ Industrial Engineering, 27(1-4), 127-130.

349. Yurdakul, M. (2004). Selection of computer-integrated manufacturing technologies using a combined analytic hierarchy process and goal programming model. Robotics $\&$ Computer-Integrated Manufacturing, 20(4), 329-340.

350. Zadeh, L.A. (1965). Fuzzy Sets. Information and Control, 8, 338-353.

351. Zaloom, V., Tolga, A., \& Chu, H. (1986). Bank funds management by goal programming. Computers 8 Industrial Engineering, 11 (1-4), 132-135.

352. Zanakis, S. H., \& Gupta, S. K. (1985). A categorized bibliographic survey of goal programming. Omega, 13(13), 211-222.

353. Zarandi, M. H. F., Sisakht, A. H., \& Davari, S. (2011). Design of a closed-loop supply chain (CLSC) model using an interactive fuzzy goal programming. The International Journal of Advanced Manufacturing Technology, 56(5-8), 809-821. 
354. Zhou, Z., Cheng, S., \& Hua, B. (2000). Supply chain optimization of continuous process industries with sustainability considerations. Computers \& Chemical Engineering, 24(2), 1151-1158.

355. Zimmerman, H.J. (1976). Description and Optimization of Fuzzy Systems. International Journal of General Systems, 2, 209-215.

356. Zimmerman, H.J. (1978). Fuzzy Programming and Linear Programming with Several Objectives Functions. Fuzzy Sets and Systems, 1, 45-55.

357. Zimmerman, H.J. (1983). Using Fuzzy Sets in Operations Research. Fuzzy Sets and Systems, 13, 201-216.

358. Zimmerman, H.J. (1988). Modelling Flexibility, Vagueness and Uncertainty in Operations Research. Investigación Operativa, 1, 7-34.

359. Zimmerman, H.J. (1990). Decision Making in Ill-Structured Environments and with Multiple Criteria. In C.A. Bana e Costa (Ed.), Readings in Multiple Criteria Decision Aid (119-151). Heidelberg: Springer-Verlag.

360. Zografos, C., \& Oglethorpe, D. (2004). Multi-criteria analysis in ecotourism: using goal programming to explore sustainable solutions. Current Issues in Tourism 7, 20-43

361. Zopounidis, C., \& Doumpos, M. (2002), Multi-Criteria Decision Aid in Financial Decision Making: Methodologies \& Literature Review. Journal of Multicriteria Decision Analysis, 11 (4-5), 167-186.

362. Zopounidis, C., Doumpos, M., \& Zanakis, S. (1999). Stock evaluation using a preference disaggregation methodology. Decision Sciences, 30, 313-336.

363. Zopounidis, C., Doumpos, M., \& Pendaraki, K., (2005). On the constraction of mutual fund portfolios: A multicriteria methodology and an application to the Greek market of equity mutual funds. European Journal of Operational Research. 163, 462-481. 